\title{
Trophic ecology influence on metal bioaccumulation in marine fish: Inference from stable isotope and fatty acid analyses
}

\author{
Le Croizier Gaël ${ }^{1,{ }^{*}}$, Schaal Gauthier ${ }^{1}$, Gallon Régis ${ }^{1}$, Fall Massal ${ }^{2}$, Le Grand Fabienne ${ }^{1}$, \\ Munaron Jean-Marie ${ }^{1}$, Rouget Marie-Laure ${ }^{3}$, Machu Eric ${ }^{4}$, Le Loc'h François ${ }^{1}$, Laë Raymond ${ }^{1}$, \\ De Morais Luis Tito ${ }^{1}$
}

${ }^{1}$ Laboratoire des Sciences de I'Environnement Marin (LEMAR), UMR 6539 CNRS/UBO/IRD/IFREMER, BP 70, 29280 Plouzané, France

${ }^{2}$ Centre de Recherches Océanographiques de Dakar-Thiaroye (CRODT/ISRA), BP 2241, Dakar, Sénégal

${ }^{3}$ Institut Universitaire Européen de la Mer (IUEM), Université de Bretagne Occidentale (UBO), CNRS UMS 3113, 29280 Plouzané, France

${ }^{4}$ Laboratoire d'Océanographie Physique et Spatiale (LOPS), UMR 6523 CNRS/IFREMER/IRD/UBO, BP70, 29280 Plouzané, France

*Corresponding author : Gaël Le Croizier, email address : gael.lecroizier@univ-brest.fr

\begin{abstract}
:
The link between trophic ecology and metal accumulation in marine fish species was investigated through a multi-tracers approach combining fatty acid (FA) and stable isotope (SI) analyses on fish from two contrasted sites on the coast of Senegal, one subjected to anthropogenic metal effluents and another one less impacted. The concentrations of thirteen trace metal elements (As, Cd, Co, Cr, Cu, Fe, $\mathrm{Li}, \mathrm{Mn}, \mathrm{Ni}, \mathrm{Pb}, \mathrm{Sn}, \mathrm{U}$, and $\mathrm{Zn}$ ) were measured in fish liver. Individuals from each site were classified into three distinct groups according to their liver FA and muscle SI compositions. Trace element concentrations were tested between groups revealing that bioaccumulation of several metals was clearly dependent on the trophic guild of fish. Furthermore, correlations between individual trophic markers and trace metals gave new insights into the determination of their origin. Fatty acids revealed relationships between the dietary regimes and metal accumulation that were not detected with stable isotopes, possibly due to the trace metal elements analysed in this study. In the region exposed to metallic inputs, the consumption of benthic preys was the main pathway for metal transfer to the fish community while in the unaffected one, pelagic preys represented the main source of metals. Within pelagic sources, metallic transfer to fish depended on phytoplankton taxa on which the food web was based, suggesting that microphytoplankton (i.e., diatoms and dinoflagellates) were a more important source of exposition than nano- and picoplankton. This study confirmed the influence of diet in the metal accumulation of marine fish communities, and proved that FAs are very useful and complementary tools to SIs to link metal accumulation in fish with their trophic ecology.
\end{abstract}




\section{Graphical abstract}

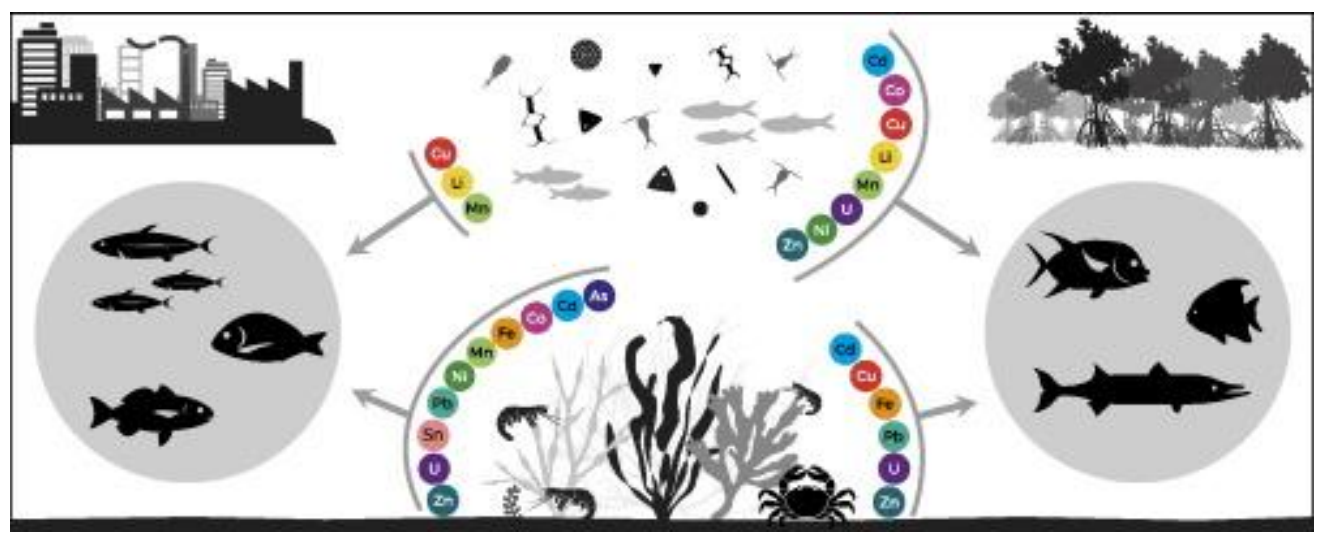

\section{Highlights}

- Stable isotope, fatty acid and metal compositions were analysed in marine fish. Metal concentrations varied according to trophic group of the fish. Benthos was the main pathway for metal transfer in an anthropised region. Metal exposition was mainly linked to pelagos in a less anthropised region. Combining stable isotope and fatty acid analyses improves determination of source in ecotoxicological studies.

Keywords : Trace elements, Biochemical tracers, Diet, Contamination, Senegal, Tropical fish

\section{Abbreviations}

- $\quad$ CCLME, Canary Current Large Marine Ecosystem;

- DHA, docosahexaenoic acid;

- EPA, eicosapentaenoic acid;

- $F A(s)$, fatty acid(s);

- FAME, fatty acid methyl esters;

- $\mathrm{KW}$, Kruskal-Wallis;

- MUFA(s), mono-unsaturated fatty acid(s);

- PCA, principal component analysis;

- PUFA(s), poly-unsaturated fatty acid(s);

- $\mathrm{SI}(\mathrm{s})$, stable isotope(s);

- SIMPER, similarity of percentages analyses;

- $\operatorname{SFA}(\mathrm{s})$, saturated fatty acid(s) 


\section{Introduction}

Increasing concerns regarding metal contamination in marine ecosystems, from both natural and anthropogenic sources, require a better comprehension of the mechanisms that drive their accumulation in organisms. Marine fish are exposed to metals via two major pathways, and even if they can assimilate dissolved metals through their gills (Jeffree et al. 2006), the main pathway is thought to be through feeding (Mathews and Fisher 2009). Because marine organisms display a wide range of accumulation patterns, trophic metal inputs therefore depend on the type of prey consumed by marine fish. Furthermore, it has been reported that fish sharing the same habitat do not necessarily share the same levels of metal accumulation (Barhoumi et al., 2009; Siscar et al., 2013), which suggests that considering the feeding habitat (e.g., benthic vs. pelagic and coastal vs. oceanic) of fish is not a sufficient approach to understand how metals are introduced to fish communities. More accurate methods aiming to characterise the trophic ecology of fish communities are therefore necessary to understand the factors affecting metal bioaccumulation. Studies investigating the link between trophic ecology and metal bioaccumulation report that an organism's metal content is not only dependant on trophic groups, but that this relationship is variable according to the metal considered (Domi et al., 2005; Metian et al., 2013). Moreover, some species can present intraspecific differences in diet, which are reflected in metal accumulation (Das et al., 2000). This highlights the need to apply trophic studies at the individual level to better understand the bioaccumulation drivers.

Over recent years, stable isotope analysis has become a very popular approach to investigate the structure of marine food webs (Valiela, 2015). Among the different strengths of this method for fish communities is the possibility to characterise trophic levels using nitrogen 
isotopes $\left(\delta^{15} \mathrm{~N}\right)$ or to discriminate benthic $v s$. pelagic or continental $v s$. oceanic inputs to the food webs using carbon isotopes $\left(\delta^{13} \mathrm{C}\right)$.

Because stable isotope analysis only provides a two-dimensional discrimination and sometimes fails to discriminate among isotopically similar sources, coupling this approach with fatty acid (hereafter FA) composition analysis has recently been suggested as a solution for a thorough understanding of marine fish trophic ecology (Stowasser et al., 2009; Couturier et al., 2013; Farias et al., 2014). Because different primary producers synthesise different fatty acids and consumers cannot efficiently synthesise them, the composition of FAs reflects the basis of food webs. FA composition analysis has therefore allowed identification of the respective roles of diatoms, dinoflagellates, bacteria or plant detritus in marine food webs (Dalsgaard et al., 2003; Kelly and Scheibling, 2012). Although a number of studies linking stable isotope composition with metal-exposed species have been published (Das et al., 2000; Domi et al., 2005; Chouvelon et al., 2012; Pethybridge et al., 2012), to our knowledge, no study has ever tried to link the metal content in fish tissues with FA trophic markers, except for mercury (McMeans et al., 2015). Furthermore, in contrast to stomach content analysis, these tracers can provide time-integrated information on the dietary habits of the fish for the last few months (Buchheister and Latour, 2010; Beckmann et al., 2014). This time scale is thus more relevant to study the chronic trophic metal exposition because trace elements can take several weeks to accumulate (Berntssen et al., 2001; Kim et al., 2006).

To investigate the link between trophic ecology and metal accumulation, a case study of the Canary Current Large Marine Ecosystem (CCLME) in Western Africa was chosen. This ecosystem is one of the world's major cold-water upwelling currents and includes several countries from Morocco to Guinea including Senegal. It ranks third in the world in terms of primary productivity (Chavez and Messié, 2009) and supports one of the largest fisheries 
among African large marine ecosystems. These fisheries provide food to local populations but also to foreign countries through the attribution of fishing licences and exportation. This marine ecosystem is prone to metal contamination due to urban effluents and industrial activities (Auger et al., 2015; Diop et al., 2015), including phosphate extraction, which is of special importance for this region (Jasinski, 2015).

Although metals of anthropogenic origin are known to accumulate in marine sediments, they can become available to marine organisms through resuspension processes, in particular due to upwelling activity. Several studies have reported the presence of metals, such as cadmium, in invertebrates from Morocco (Banaoui et al., 2004), Mauritania (Everaarts et al., 1993; Sidoumou et al., 1999) and Senegal (Bodin et al., 2013). Concerning fish communities, although some data are available for the northern part of the CCLME (Roméo et al., 1999; Sidoumou et al., 2005; Chahid et al., 2014), only recent studies have investigated the metal content in fish from the coast of Senegal (Diop et al., 2016a, 2016b). Improved knowledge in this area is of special importance because coastal sediments and waters from this area are known to be impacted by toxic metals such as cadmium, chromium, nickel and lead (Diop et al., 2012, 2014; Bodin et al., 2013; Diop et al., 2015).

In the present study, a multi-tracers approach combining fatty acid and stable isotope analyses was used to investigate the trophic ecology of different fish species from the coast of Senegal. In addition, a metal content analysis was performed on the liver, which is known to be an organ highly involved in metal bioaccumulation by marine fish (Berntssen et al., 2001; Kim et al., 2006; Siscar et al., 2014).

The main objective of this work was to study the repartition of metals between different fish groups characterised by different trophic marker compositions. In addition, correlations 
between these tracers and trace metal elements were investigated to better understand the pathways leading to the contamination of fish communities.

\section{Material and methods}

\subsection{Study area and sampling}

Two sites that were presumed to be impacted differently by metallic contamination were selected (Fig. 1).

The first one was located in the offshore area of Dakar Bay, where urban and industrial wastewaters are directly discharged into the bay (Diop et al., 2012, 2014; Diop et al., 2015).

The second one was located off the Casamance River Estuary, at the extreme southern area of Senegal. Although there are no existing data on metal concentration in marine organisms for this region, this place was considered to be less impacted because of the absence of large cities and/or significant industrial activity.

The samples were collected during the AWA project (Ecosystem Approach to the management of fisheries and the marine environment in West African waters) scientific cruise in March 2014 aboard the RV Thalassa. The fish were caught with a bottom trawl net, packed in plastic bags and frozen on board at $-20{ }^{\circ} \mathrm{C}$. Once at the laboratory, the fish were weighed (wet weight) and measured (total length) (Table 1). They were then dissected with ceramic tools to avoid metal contamination, and the liver and a piece of dorsal muscle (a standardised cut on the dorsal muscle just behind the head) were collected. The liver was split into two samples, one for trace metal analysis and one for the fatty acid composition analysis. Stable isotope analyses were conducted on dorsal muscle samples only. Five replicates were analysed for each species and for each type of analysis. 


\subsection{Trace metal analysis}

Liver samples for trace metal analysis were freeze-dried, ground, and stored in individual plastic vials. Approximately $80 \mathrm{mg}$ of the dried samples were digested in a mixture of $7 \mathrm{ml}$ of $70 \% \mathrm{HNO}_{3}$ and $1 \mathrm{ml}$ of $30 \% \mathrm{H}_{2} \mathrm{O}_{2}$ (both of ultrapure quality) in Teflon vessels. Mineralization was performed in a microwave oven (Ethos One, Milestone) during $15 \mathrm{~min}$ with increasing temperature until $200{ }^{\circ} \mathrm{C}$, followed by $15 \mathrm{~min}$ at $200{ }^{\circ} \mathrm{C}(1500 \mathrm{~W})$ and $90 \mathrm{~min}$ of cooling. The samples were then evaporated on a hotplate at $100{ }^{\circ} \mathrm{C}$, resolubilised with $2 \mathrm{ml}$ of $\mathrm{HNO}_{3}$, and diluted to $50 \mathrm{ml}$ with Milli-Q quality water (Merck Millipore). A total of 13 elements: arsenic $(\mathrm{As})$, cadmium $(\mathrm{Cd})$, cobalt $(\mathrm{Co})$, chromium $(\mathrm{Cr})$, copper $(\mathrm{Cu})$, iron $(\mathrm{Fe})$, lithium $(\mathrm{Li})$, manganese $(\mathrm{Mn})$, nickel $(\mathrm{Ni})$, lead $(\mathrm{Pb})$, thin $(\mathrm{Sn})$, uranium $(\mathrm{U})$ and zinc $(\mathrm{Zn})$ were analysed using an ICP Q-MS (X Series 2, Thermo Scientific) at the Pôle de Spectrométrie Océan (PSO, Plouzané, France) with an internal solution of Rhodium. These elements were selected for their reported occurrence in the marine environment of Senegal (Bodin et al., 2013; Diop et al., 2015, 2016). Reference materials (fish protein DORM-4 and lobster hepato-pancreas TORT-2, NRCC) were treated and analysed in the same way as the samples. The results for reference materials displayed mean element recoveries ranging from $84 \%$ to $132 \%$ for DORM-4 and $89 \%$ to $131 \%$ for TORT-2. Blanks were included in each analytical batch. The detection limits $\left(\mu \mathrm{g} \cdot \mathrm{g}^{-1}\right.$ dry wt) were $0.001(\mathrm{Ni}), 0.003(\mathrm{Co}), 0.016$ (As, $\mathrm{Pb}), 0.017(\mathrm{U}), 0.018(\mathrm{Cr}), 0.054(\mathrm{Li}), 0.133(\mathrm{Cu}), 0.15(\mathrm{Cd}), 0.19(\mathrm{Mn}), 0.278(\mathrm{Zn}), 1.61(\mathrm{Sn})$ and $17.83(\mathrm{Fe})$. All of the element concentrations (ppm) are provided as a dry weight basis $\left(\mu \mathrm{g} \cdot \mathrm{g}^{-1}\right.$ dry wt).

\subsection{Stable isotopes}

The muscle samples for the analysis of stable isotopes were freeze-dried and ground into a fine and homogeneous powder. Approximately $350 \mu \mathrm{g}$ of powder was then weighed in tin 
capsules for isotopic analysis. The samples were analysed by continuous flow on a Thermo Scientific Flash EA 2000 elemental analyser coupled to a Delta V Plus mass spectrometer at the Pôle de Spectrométrie Océan (PSO, Plouzané, France). The results are expressed in standard $\delta$ notation based on international standards (Vienna Pee Dee Belemnite for $\delta^{13} \mathrm{C}$ and atmospheric nitrogen for $\delta^{15} \mathrm{~N}$ ) following the equation $\delta^{13} \mathrm{C}$ or $\delta^{15} \mathrm{~N}=\left[\left(\mathrm{R}_{\text {sample }} / \mathrm{R}_{\text {standard }}\right)-1\right] \times 10^{3}$ (in \%o), where $\mathrm{R}$ is ${ }^{13} \mathrm{C} /{ }^{12} \mathrm{C}$ or ${ }^{15} \mathrm{~N} /{ }^{14} \mathrm{~N}$.

The samples were not delipidated, because muscle generally contains a lower amount of lipids than other organs in fish (Njinkoué et al., 2002). However, since lipid content can impact $\delta^{13} \mathrm{C}, \mathrm{C} / \mathrm{N}$ ratios were measured. They exceeded 3.5 for a few samples (Supplementary material, Table 1) and therefore a mathematical normalisation was applied, following the equation $\delta^{13} \mathrm{C}_{\text {normalised }}=\delta^{13} \mathrm{C}_{\text {untreated }}-3.32+0.99 \cdot \mathrm{C} / \mathrm{N}$ (Post et al., 2007).

International isotopic standards of known $\delta^{15} \mathrm{~N}$ and $\delta^{13} \mathrm{C}$ were used: IAEA-600 Caffeine, IAEA-CH-6 Sucrose, IAEA-N-1 and IAEA-N-2 Ammonium Sulphate. A home standard (Thermo Acetanilide) was used for experimental precision (based on the standard deviation of the replicates of the internal standard) and indicated an analytical precision of $\pm 0.11 \%$ ofor $\delta^{13} \mathrm{C}$ and $\pm 0.07 \%$ for $\delta^{15} \mathrm{~N}$.

\subsection{Fatty acids}

\subsubsection{Lipid extraction}

After dissection, the liver samples (approximately $300 \mathrm{mg}$ each) were immediately put in glass tubes previously heated for $6 \mathrm{~h}$ at $450{ }^{\circ} \mathrm{C}$ and containing $6 \mathrm{~mL}$ of a chloroform/methanol mixture $(2 / 1, \mathrm{v} / \mathrm{v})$, flushed with nitrogen and stored at $-20{ }^{\circ} \mathrm{C}$ before analysis. The samples were then manually ground in the mixture with a Dounce homogeniser and vortexed.

\subsubsection{Separation}


Neutral lipids were isolated following the method used by Le Grand et al. (2014). An aliquot of total lipid extract $(1 \mathrm{~mL})$ was evaporated to dryness under nitrogen, recovered with three 0.5-mL washings of chloroform/methanol $(98 / 2, \mathrm{v} / \mathrm{v})$ and deposited at the top of a silica gel micro-column (Pasteur pipette of $40 \mathrm{~mm} \times 5 \mathrm{~mm}$ i.d., plugged with glass wool and filled with silica gel 60 , which were both previously heated for $6 \mathrm{~h}$ at $450{ }^{\circ} \mathrm{C}$ and deactivated with $6 \%$ water by weight). Only neutral lipids (NL), including triglycerides, free fatty acids and sterols, were eluted with $10 \mathrm{~mL}$ of chloroform/methanol $(98 / 2, \mathrm{v} / \mathrm{v})$ and collected in $20-\mathrm{mL}$ glass vials. After evaporation to a dryness under nitrogen, the NL fraction was recovered and transferred to $7-\mathrm{mL}$ vials with three $1-\mathrm{mL}$ washings of chloroform/methanol $(98 / 2, \mathrm{v} / \mathrm{v})$.

\subsubsection{Transesterification}

After the addition of tricosanoic acid (23:0) as an internal standard and evaporation to dryness under nitrogen, the fatty acid methyl esters (FAME) were obtained using a method modified from Le Grand et al. (2014). A total of $0.8 \mathrm{~mL}$ of a sulphuric acid solution (3.8\% in methanol) was added, vortexed and heated for $10 \mathrm{~min}$ at $100{ }^{\circ} \mathrm{C}$. Before gas chromatography analysis, $0.8 \mathrm{~mL}$ of hexane was added and the organic phase containing FAME was washed three times with $1.5 \mathrm{~mL}$ of hexane-saturated distilled water. The organic phase was finally transferred to tapering vials and stored at $-20^{\circ} \mathrm{C}$.

\subsubsection{Gas chromatography analysis}

FAMEs were analysed in a Varian CP 8400 gas chromatograph equipped with a split/splitless injector and a flame-ionization detector. FAMEs were identified using two different capillary columns (ZBWAX - $30 \mathrm{~m} \times 0.25 \mathrm{~mm}$ i.d., $0.25-\mu \mathrm{m}$ thickness, Phenomenex; and ZB-5HT - 30 $\mathrm{m} \times 0.25 \mathrm{~mm}$ i.d., $0.25-\mu \mathrm{m}$ thickness, Phenomenex) by means of a standard 37-component FAME mix (Sigma) and other known standard mixtures. The FAs were expressed as the molar percentage of the total FA content. 


\subsection{Data analyses}

Only FAs accounting for $\geq 0.5 \%$ of total FA in at least one fish sample were included in the data analyses. The groups inferred by stable isotope and fatty acid analyses were derived from the result of a hierarchical cluster analysis (Ward's clustering method). Similarity of percentages analyses (SIMPER) were used to identify the fatty acids that were the most discriminant between the groups. Principal component analyses (PCA) were performed to investigate the variation in fatty acids profiles between individual fish from the same community. The groups derived from the result of the clustering and FAs accounted for more than $75 \%$ of the dissimilarity contribution between the groups in the SIMPER routine and were shown in the PCA.

All of the data submitted to the statistical tests were first checked for normality (ShapiroWilks test) and for homogeneity of variances (Bartlett test). When these conditions were satisfied, parametric tests were used in the subsequent analysis; otherwise, non-parametric analogues were used. Pearson and Spearman correlation coefficient tests were used to investigate the correlation between the variables (stable isotopes, fatty acids and metal concentrations). Significance of the RV correlation coefficient, which is a multivariate generalisation of the Pearson correlation coefficient, was tested by permutation to measure the closeness of the SI and FA matrices.

One-way ANOVAs followed by Tukey's HSD tests, and Kruskal-Wallis (KW) tests followed by Conover-Iman multiple comparison tests with Bonferroni's adjustment method, were performed to test differences between groups in muscle $\delta^{13} \mathrm{C}$ and $\delta^{15} \mathrm{~N}$ values, and in metal concentration for each element. All of the statistical analyses were performed using the free software R (R Development Core Team 2010). 


\section{Results}

\subsection{Stable isotopes}

The stable isotope $\left(\delta^{13} \mathrm{C}\right.$ and $\left.\delta^{15} \mathrm{~N}\right)$ composition of fish from the region of Dakar highlighted three main groups (Fig. 2A). These three groups were significantly different in their $\delta^{15} \mathrm{~N}$ (KW test, $\mathrm{p}<0.001$ ). The first one contained only individuals of the chub mackerel Scomber japonicus. This group displayed the lowest $\delta^{15} \mathrm{~N}$ (from 7.8 to $8.5 \%$ ) and lower $\delta^{13} \mathrm{C}(-17.2$ to $16.3 \%$ ) than group three (ANOVA, $\mathrm{p}<0.001)$

The second group was characterised by intermediate $\delta^{15} \mathrm{~N}$ (9.9 to $11.2 \%$ ) and also lower $\delta^{13} \mathrm{C}$ $(-16.7$ to $-14.7 \%$ ) than group three (ANOVA, $p<0.001)$. This second group included all individuals of the bogue Boops boops and the Cunene horse mackerel Trachurus trecae and one individual of the West African goatfish Pseudupeneus prayensis. The third group showed both the highest $\delta^{15} \mathrm{~N}\left(11.4\right.$ to $12.9 \%$ ) and the highest $\delta^{13} \mathrm{C}(-15.9$ to $-14.5 \%)$. This third group included all individuals of the Senegal seabream Diplodus bellottii and the false scad $C$. rhonchus, and most $P$. prayensis individuals.

Samples from Casamance were also classified into three groups (Fig. 2B). The first one was mainly composed of individuals of the Atlantic bumper Chloroscombrus chrysurus and had lower $\delta^{13} \mathrm{C}(-17.2$ to $-16.0 \%$ ) than other groups (ANOVA, $\mathrm{p}<0.001)$ and lower $\delta^{15} \mathrm{~N}(12.3$ to 13.7\%o) than group two. This last group was characterised by higher $\delta^{13} \mathrm{C}(-16.2$ to $-14.8 \%$ o than group one and higher $\delta^{15} \mathrm{~N}(14.0$ to $14.7 \%$ ) than the other groups. The composition of this group was heterogeneous and included fish from the six species analysed except from the Lesser African threadfin Galeoides decadactylus. Group three had similar $\delta^{15} \mathrm{~N}$ (12.4 to 13.7\%o) but higher $\delta^{13} \mathrm{C}\left(-15.9\right.$ to $-15.2 \%$ ) than group one and similar $\delta^{13} \mathrm{C}$ but lower $\delta^{15} \mathrm{~N}$ than group two. It mainly included individuals from C. rhonchus and G. decadactylus. 


\subsection{Fatty acid analysis}

For the fish community of both Dakar and Casamance, a total of 34 fatty acids represented more than $0.5 \%$ of the total FA in at least one sample and were therefore considered for further analysis.

A hierarchical cluster analysis (Ward's clustering method) allowed the clear separation of three groups in Dakar based on their global FA composition. Group one (composed of $T$. trecae) was characterised by a lower proportion of saturated fatty acids (SFAs) and a higher proportion of poly-unsaturated fatty acids (PUFAs), which accounted for half of the total fatty acids, than the other groups (Table 2). Group two (B. boops, D. Bellottii, P. prayensis) presented an intermediate amount of SFAs but the highest content of mono-unsaturated fatty acids (MUFAs) and the lowest of PUFAs. Group three (C. rhonchus, D. Bellottii, $P$. Prayensis) showed the highest content of SFAs and intermediate levels of MUFAs. The FA distribution within SFAs and PUFAs did not differ strongly between the different groups. The most important individual FAs were 16:0, 18:0, and 14:0 for SFAs and 20:5n-3, 22:6n-3, and 22:5n-3 for PUFAs. However, MUFA partitioning was rather different with 16:1n-7, 18:1n-9, and 22:1n-11 dominating group one, whereas $18: 1 n-9,16: 1 n-7$, and $18: 1 n-7$ were the most abundant in groups two and three.

The principal component analysis (Fig 3A) shows the separation between the three groups in Dakar and the fatty acids responsible for the inter-group differences. Group one contained all S. japonicus and was characterised by an abundance of 22:1n-11 and n-3 PUFAs such as 20:5n-3, 22:5n-3 and 22:6n-3. The second group was mostly characterised by its high amount of 16:0, 18:1n-9 and to a lesser extent $22: 1 \mathrm{n}-11$ and 16:1n-7. It included all of the T. trecae and $C$. rhonchus and three individuals from B. boops. The third group showed a dominance of various fatty acids such as 16:0, 18:0, 18:1n-7 and 20:4n-6. All of the D. bellottii and $P$. prayensis individuals were in this group, along with the two individuals of B. boops. All of 
the individuals of the same species were classified in one group, except $B$. boops, which was split between two groups.

Fish from Casamance were also clearly separated into three groups by the hierarchical cluster analysis, but all the species were split into two groups. The repartition of fatty acids between the different classes was less variable from one group to another in this region. Indeed, similar contents of SFAs were found between the groups with group one only differing from the others by a lower amount of MUFAs and higher amount of PUFAs (Table 3). The dominant FAs within the SFA class were 16:0, 18:0 and 14:0, and within the MUFAs, they were 18:1n9, 16:1n-7 and 18:1n-7. The PUFAs were mostly composed of 22:6n-3, 20:5n-3 and 22:5n-3 in groups one and two and of 20:5n-3, 22:6n-3 and 20:4n-6 in group three.

The principal component analysis (Fig. 3B) highlighted that the first group was discriminated by the n-3 PUFAs 22:6n-3, 20:5n-3 and 22:5n-3 and to a lesser extent by 18:0. Group two was mostly characterised by 18:1n-9. Group three was discriminated from the other groups by its contents of 16:1n-7, 18:1n-7 and 16:0. Only two species, C. chrysurus in group one and $G$. decadactylus in group three, were classified in only one group. This demonstrates the high intra-specific variability in terms of trophic markers existing within the species sampled at this location.

\subsection{Trace metal analysis}

For some of the trace elements analysed, the concentrations in the liver of the fish sampled in Dakar varied significantly between the groups identified from the stable isotope (SI groups) and the fatty acid (FA groups) analyses (Fig. 4A). All the differences discussed below were statistically significant $(\mathrm{p}<0.05)$. In the SI groups, a lower level of Li $(0.09 \mathrm{ppm} \mathrm{dw})$ was found in group three than in other groups $(0.45 \mathrm{ppm} \mathrm{dw}$ for group one and $1.95 \mathrm{ppm} \mathrm{dw}$ for 
group two), whereas $\mathrm{Pb}$ was more abundant in group three ( $0.15 \mathrm{ppm} \mathrm{dw})$ compared to group one $(0.05 \mathrm{ppm} \mathrm{dw})$. Distribution of the individual fish inferred by stable isotopes and fatty acids were poorly correlated in Dakar $(\mathrm{RV}=0.19 ; \mathrm{p}<0.05)$. As a consequence of the differences in the composition of the two types of groups (SI and FA groups), the FA groups showed many other differences in the concentrations of trace elements. Group one displayed a higher level of $\mathrm{Mn}$ and $\mathrm{Pb}$ than group two. In group three, $\mathrm{As}, \mathrm{Cd}, \mathrm{Co}, \mathrm{Fe}, \mathrm{Pb}$ and $\mathrm{Zn}$ were more abundant than in the two other groups. Likewise, Ni concentration was higher than in group two and Sn concentration was higher than in group one.

In the fish community from Casamance, significant differences also existed between the different groups in terms of the metal concentration in the liver (Fig. 4B). According to the SI groups, only one element varied depending on the trophic preferences. Li was indeed more abundant in group one than in group three. Distributions of the fish through SI and FA analyses were not significantly correlated in Casamance. More differences were also found in the metal contents between the FA groups. Group one displayed higher levels of $\mathrm{Co}, \mathrm{Cu}, \mathrm{Fe}$, $\mathrm{Li}, \mathrm{Sn}$ and $\mathrm{Zn}$ than group three. Group one also contained more Li than group two. Finally, group two showed more $\mathrm{Fe}$ and $\mathrm{Zn}$ than group three.

\subsection{Correlations between metals and trophic markers}

Considering only the relationships that indicated strong correlations (arbitrarily determined for correlation coefficients $>0.5$ ), very few metals were correlated with stable isotope ratios. Fe was positively correlated with $\delta^{15} \mathrm{~N}$ for fish from Dakar (Table 3), whereas Li was negatively correlated with $\delta^{15} \mathrm{~N}$ in Dakar and with $\delta^{13} \mathrm{C}$ in Casamance (Table 4). $\mathrm{Pb}$ was positively correlated with $\delta^{13} \mathrm{C}$ in Casamance. However, all of the trace metal elements were positively correlated with at least one fatty acid, except $\mathrm{Cr}$ in Dakar (Table 3) and As, Cr and 
$\mathrm{Sn}$ in Casamance (Table 4). $\mathrm{Zn}, \mathrm{Mn}$ and $\mathrm{Cu}$ were found to be negatively correlated with 18:1n-9 in Dakar, whereas Fe and Zn were negatively correlated with 16:1n-7 in Casamance.

\section{Discussion}

\subsection{Stable isotope analysis}

In marine ecosystems, stable isotopes are commonly used to infer trophic levels through $\delta^{15} \mathrm{~N}$ values and offshore versus inshore, or pelagic versus benthic inputs through $\delta^{13} \mathrm{C}$ values. Moreover, the position of individuals in bivariate isotope space (the isotopic niche) is considered a convenient proxy for the trophic niche (Layman et al., 2012). Because carbon and nitrogen half-lives are higher in muscle than in liver tissues (Buchheister and Latour, 2010), and trace metal elements can take several months to accumulate (Berntssen et al., 2001), muscle stable isotopes signature as been widely used in ecotoxicological studies (Domi et al., 2005; Chouvelon et al., 2012).

Individual fish from Dakar occupied three distinct trophic niches. The first one (group one) was characterised by low $\delta^{15} \mathrm{~N}$, which reflected a low trophic position within the fish community and a low $\delta^{13} \mathrm{C}$ that indicated pelagic/offshore dietary habits. Trophic level is known to change during ontogeny, even for small pelagic fish like $S$. japonicus (Costalago et al., 2012) which alone constitute the first group. The low trophic level of this group can thus also be explained by the small size of the fish sampled for this species (Table 1).

The second group, which showed similar $\delta^{13} \mathrm{C}$ but higher $\delta^{15} \mathrm{~N}$, may also feed on pelagic prey but at an intermediate trophic level. For B. boops individuals, which all belonged to this group, this is in accordance with the relatively low trophic level reported for this species (TL = 3; Table 1), whereas for T. trecae, the reported trophic level is similar to that of species belonging to the third group $(\mathrm{TL}=3.5$; Table 1$)$. It can also be explained by the fact that fish sampled here were immature and thus might feed at a lower trophic level than adults. 
Finally, the third group occupied a niche characterised by higher $\delta^{15} \mathrm{~N}$ but lower $\delta^{13} \mathrm{C}$ than the two other groups. The fish in this group may feed on more benthic/coastal prey and at a higher trophic level than other groups. The three fish species constituting this group are known to share similar trophic level (close to 3.5; Table 1) which supports the relevance of their stable isotopes clustering.

In the fish community of Casamance, three main isotopic niches were also observed. Group one contained fish with both low $\delta^{13} \mathrm{C}$ and $\delta^{15} \mathrm{~N}$, which suggested that the fish were feeding on pelagic prey of lower trophic levels. In contrast, other groups displayed higher $\delta^{13} \mathrm{C}$, which showed a more benthic/coastal origin of the prey.

Among them, group two was also characterised by higher $\delta^{15} \mathrm{~N}$ signatures than the two other groups, which suggested a higher trophic level. It contained various species, mostly with reported high trophic levels like the Guachanche barracuda Sphyraena guachancho (4.4; Table 1).

Finally, group three shared the $\delta^{15} \mathrm{~N}$ signature of group one, which is in accordance with the reported trophic levels of $C$. chrysurus which mostly composed group one (3.5; Table 1) and G. decadactylus (3.6; Table 1) which mostly belonged to group three. On the other hand, the bigeye grunt Brachydeuterus auritus which also showed similar $\delta^{15} \mathrm{~N}$ was previously known to have a lower trophic level than these species (3; Table 1).

\subsection{Fatty acid analysis}

Fish sampled offshore of Dakar were structured in three major groups based on their FA composition. The first group only included S. japonicus, which also differed from other species based on its composition of stable isotopes. Except for this species, FA groups poorly fitted SI groups, which strengthened the need to use different tools to characterise dietary habits. 
This species was characterised by its high amount of n-3 PUFAs ( $\sum$ n-3, Table 2). Because 20:5n-3 (eicosapentaenoic acid, EPA) is commonly considered a marker of diatoms (e.g., Meziane and Tsuchiya, 2000; Kharlamenko et al., 2001; Alfaro et al., 2006)) and 22:6n-3 (docosahexaenoic acid, DHA) is a marker of dinoflagellates, the ratio of these two FAs has been used to determine the predominant taxa in phytoplankton (Parrish et al., 2000). The EPA/DHA ratio in this first group was higher than one, which suggests that $S$. japonicus relies on higher proportions of a diatoms-based food web (Alfaro et al., 2006). The first group was also characterised by a higher content of $22: 1 n-11$ than group three. This FA is known to be synthesised in high proportions by copepods and has been commonly used to evaluate the reliance of fish species on copepod-based pelagic food webs (Stowasser et al., 2009, 2012). Therefore, the FA composition of this group fits with the previously described diet of immature chub mackerels, which have been reported to rely on copepods and euphausiids in the North-West African shelf (Castro, 1993). Considering these observations, S. japonicus from the region of Dakar may therefore rely on herbivorous zooplankton feeding on diatoms, which is in accordance with the low $\delta^{13} \mathrm{C}$ and $\delta^{15} \mathrm{~N}$ observed for this species.

The second group contained individuals from B. boops, C. rhonchus and T. trecae and was characterised by its high content of $16: 0$, which is a ubiquitous FA that most organisms are able to synthesise de novo. Even if its abundance varies among taxa, it is difficult to attribute its presence to a specific type of prey. This group also showed high amounts of $18: 1 \mathrm{n}-9$, a major FA in most marine animals, which are able to biosynthesise it de novo by chain elongation from 18:0 (Kelly and Scheibling 2012). In benthic environments, this FA has been identified in various dietary sources, such as brown algae, mangrove detritus or animal material (Bachok et al., 2003; Alfaro et al., 2006; Jaschinski et al., 2011). In pelagic ecosystems, it has been used as a marker of carnivory (Pethybridge et al., 2014). However, 
this FA can also be abundant in phytoplankton species (Dalsgaard et al., 2003; Escribano and Pérez, 2010), and its presence in higher trophic levels may depend more on its abundance on basic components of the food web than on the trophic level of the consumer. At high and temperate latitudes, the seasonal food supply induces the storage of lipid reserves by zooplankton (Kattner and Hagen, 2009). Zooplankton from these regions are known to display high proportions of 18:1n-9 in these reserves (Lee et al., 2006). In tropical and subtropical waters, copepods from the oligotrophic epipelagic environment are characterised by continuous feeding and generally do not accumulate lipids in significant amounts in the upper $250 \mathrm{~m}$ of the water. In contrast, in deeper environments, copepods are exposed to lower prey densities and feed mainly through episodic sedimentation events, which results in higher energy storage than for epipelagic copepods including higher 18:1n-9 levels (Teuber et al., 2014). Upwelling regions are characterised by periodic high productivity events, which are comparable to the seasonal food input at temperate and high latitudes and may thus result in similar lipid storage strategies. It has been reported that copepods feeding on pico- and nanoplankton also displayed higher 18:1n-9 levels than those feeding on microplankton, where this FA can be absent (Escribano and Pérez, 2010). Here, 18:1n-9 was strongly negatively correlated with EPA (diatoms marker) and DHA (dinoflagellates marker) (Supplementary material, Table 2), which where the least abundant in group two. As diatoms and dinoflagellates are the major components of microplankton (Anabalón et al. 2014), this suggests that this group relies on small-sized fractions of phytoplankton. Moreover, this group was also characterised by a high content of $16: 1 \mathrm{n}-7$, which is generally considered a diatoms marker (e.g., Richoux and Froneman 2008) but has also been reported as abundant in bacteria (Kharlamenko et al. 2001) and is abundant in marine sediments (Perry et al. 1979). Here, the fact that $16: 1 \mathrm{n}-7$ is negatively correlated with the dinoflagellates marker $22: 6 \mathrm{n}-3$ suggests a benthic origin. 
Thus, the FA compositions for these individuals were in accordance with the reported diets of the species included in this group. Indeed, for the class size sampled here (see Table 1), $T$. trecae is known to feed on planktonic crustaceans, and C. rhonchus presents a diet composed of small planktivorous fish and planktonic and benthic crustaceans (Boëly et al., 1973; Sley et al., 2008), whereas B. boops shows an omnivorous diet composed of fish, benthic crustaceans and zooplanktonic prey (Derbal and Hichem Kara, 2008). In group two, the abundance of 18:1n-9 may reflect the consumption of pelagic prey, zooplankton or small fish, whereas the 16:1n-7 signature may result from the ingestion of benthic crustaceans.

The third group gathered three species, B. boops, D. Bellottii, P. Prayensis, and was discriminated by 18:0, also a ubiquitous FA synthesised through elongation of 16:0. This group was also characterised by $18: 1 \mathrm{n}-7$, which is commonly used to assess the bacterial contribution in the marine food web (Meziane and Tsuchiya, 2000; Kharlamenko et al., 2001; Alfaro et al., 2006), and 20:4n-6. The latter has been reported to be abundant in brown and red algae (Kelly and Scheibling, 2012) but can be found in high proportions in marine invertebrates from sites devoid of macroalgae, which is the case for most of the Senegal coastline. Therefore, the authors hypothesised that this FA may results from feeding upon drift algae, phytodetritus or microbial mats (Cook et al., 2000). Many other primary producers are also able to synthesise this FA, such as diatoms (Dunstan, et al. 1993), fungi and protozoa (Kim et al., 1998; Kharlamenko et al., 2001). It has also been shown in controlled feeding and in situ studies that this FA can be selectively retained or biosynthesised de novo by bivalves and crustaceans (Soudant et al., 1996; Budge et al., 2001; Kelly et al., 2009). Finally, it has been used to identify the consumption of benthic prey in marine fish (Stowasser et al., 2009). In the present study, it was positively correlated with 22:4n-6 alongside the 22:5n-6 (Supplementary material, Table 2), which can all be synthesised from 20:4n-6. Because this 
group is also characterised by high bacterial marker content, such as 15:0, it is likely that high amounts of (n-6) PUFAs in this group come from the assimilation of phytodetritus and the microphytobenthos. Again, this is in accordance with the described ecology of the species included in this group, which is dominated by two benthic fish. D. bellottii shows an omnivorous diet composed of algae, bivalves and crustaceans (Horta et al., 2004), whereas $P$. prayensis feeds mainly on benthic invertebrates (Caverivière, 1993).

In the fish sampled in Casamance, the first group was mainly discriminated from others by its high content of n-3 PUFAs (Fig. 3B). As observed in group one from Dakar, this group may also rely on a pelagic food web. However, an EPA/DHA ratio lower than one indicates that dinoflagellates were more important than for fish from Dakar. This group is dominated by $C$. chrysurus, which is known to be a pelagic particulate feeder (Faye et al., 2011), and $C$. rhonchus. The latter is an opportunistic piscivorous species for the size class sampled in Casamance (see Table 1) and feeds at almost $70 \%$ on planktivorous fish, mainly on anchovies Engraulis encrasicolus and to a lesser extent on clupeids such as the round sardinella Sardinella aurita (Boëly et al., 1973; Sley et al., 2008). Anchovies are known to contain high levels of DHA (Pethybridge et al., 2014), which seems to confirm this species as the dominant prey for C. rhonchus.

Two individuals of the barracuda $S$. guachancho were also found in this group. This piscivorous species feeds mainly on small pelagic fish such as Sardinella spp., T. trecae and C. chrysurus for the size class of individuals sampled (see Table 1; Akadje et al., 2013). Hence, it is not surprising to find this species alongside $C$. chrysurus, which confirms that the FA composition of a predator reflects that of its prey. Therefore, group one mostly contains phytoplankton-feeding species and their direct predators, which share a similar FA composition. 
The second group in Casamance was discriminated from others by 18:1n-9 and from group one by 16:1n-7, which is similar to what was observed for fish from Dakar. This group was dominated by $B$. auritus, which is known to feed on a variety of sources, including copepods and the African moonfish Selene dorsalis, which feeds on pelagic fish and crustaceans (Caverivière, 1993; Diouf, 1996). It also included three barracudas that may feed on different species of forage fish than their conspecifics belonging to group one. Because $C$. chrysurus and Sardinella species are characterised by high levels of n-3 PUFAs (Njinkoué et al., 2002), it can be hypothesised that barracudas from group two fed on T. trecae instead, which showed a high level of 18:1n-9 in Dakar.

In summary, group two gathers secondary and tertiary consumers and belongs to a pelagic food web based on phytoplankton phyla other than diatoms and dinoflagellates.

G. decadactylus was the only species classified in the third group for fish sampled in Casamance. This species was characterised by its content of the benthic marker $16: 1 \mathrm{n}-7$ and 18:1n-7. The latter has been linked to diatoms (Dalsgaard et al., 2003) and was thus used as an herbivory marker for copepods in the Benguela upwelling system (Schukat et al., 2014). It has also been found alongside 16:1n-7 in high amounts in the surface sediments of the Humbolt upwelling ecosystem (Gutiérrez et al., 2012) and is commonly used to assess the bacterial contribution in marine food webs (Meziane and Tsuchiya, 2000; Kharlamenko et al., 2001; Alfaro et al., 2006). Moreover, in this study, this FA was positively correlated to iso17:0 (Supplementary material, Table 3), which is known to be predominantly synthesised by bacteria (Volkman et al., 1980) and used as a bacterial marker in sediments (Rajendran et al., 1993, 1992). This suggests that here, 18:1n-7 must be more associated with the benthic ecosystem than with the pelagic one. This is in accordance with the described ecology of $G$. 
decadactylus, which leaves over sandy and muddy bottoms and feeds mainly on benthic crustaceans (Caverivière, 1993).

\subsection{Metal concentration differences between trophic groups}

In the present study, the trophic groups inferred by the analysis of dual stable isotopes poorly explained the variability in terms of bioaccumulation. In Dakar, the association of coastal/benthic food intake with a higher trophic level only led to a largest accumulation of $\mathrm{Pb}$, whereas in Casamance, only Li was dominant in fish showing offshore/pelagic habits combined with low trophic levels. Some studies have successfully associated the contents of some metals like mercury $(\mathrm{Hg})$ and $\mathrm{Cd}$ with the isotopic niche of marine fish species (Das et al., 2000; Domi et al., 2005). However, most of the trace metal elements are in general not correlated to $\delta^{15} \mathrm{~N}$ nor $\delta^{13} \mathrm{C}$ in fish communities (Ofukany et al., 2014; Goutte et al., 2015). The distribution of the elements analysed here could not be only attributed to the feeding habitat or trophic level, which implied no biomagnification (i.e. increase with $\delta^{15} \mathrm{~N}$ ) like it is well documented for $\mathrm{Hg}$ (McMeans et al., 2010; Pethybridge et al., 2012). Hence, a more precise determination of the food sources was necessary to understand the pathways of metal accumulation.

To our knowledge, there is no published study using fatty acids to infer the dietary origin of metal accumulation in a marine fish community. In this study, we attempted to demonstrate how bioaccumulation of several trace metal elements relates to the trophic preferences of the fish using the FA composition.

In Dakar, were anthropogenic inputs occurred, the consumption of benthic prey led to a higher contamination of $\mathrm{Cd}, \mathrm{Ni}, \mathrm{Pb}, \mathrm{Fe}, \mathrm{Co}, \mathrm{Zn}$, As, and Sn (Fig. 4A). This was highlighted by the positive correlation found between these elements and at least one FA from a benthic 
origin (Table 3). These FAs included bacterial markers, such as iso17:0, ant17:0 and 15:0 (Volkman et al., 1980), which are characteristic of sediment communities (Rajendran et al., 1993, 1992) and were more abundant in group three ( $\sum$ BAFA). This benthic FA pool also contained n-6 PUFAs from phytodetritus or the microphytobenthos, which were, like BAFAs, more abundant in group three $\left(\sum n-6\right)$. Within the pelagic ecosystem, the microphytoplanktonbased food web seemed to be a major pathway for the transfer of $\mathrm{Mn}, \mathrm{Pb}$ and $\mathrm{Zn}$ to fish as revealed by the negative correlation between $\mathrm{Mn}$ and $\mathrm{Zn}$ and the nano- and picoplankton marker 18:1n-9 (Table 3), which may be less impacted by these elements. Indeed, taxonomic differences in the plankton metal concentration can exist as shown between diatoms, flagellates and picophytoplankton (Twining and Baines, 2013; Twining et al., 2015). These differences can also vary between ocean basins and the elements considered. In this fish community, pelagic and benthic predators had different pathways for metal accumulation.

Conversely, in the community from Casamance, feeding on pelagic prey seemed to induce a higher accumulation of Fe and $\mathrm{Zn}$ (Fig. 4B) as indicated by the negative correlation between these elements and the benthic marker 16:1n-7 characterising group three and the positive correlation between $\mathrm{Zn}$ and DHA, a dinoflagellates marker that was found in higher proportions in groups one and two. Furthermore, fish belonging to the microphytoplanktonbased food web (group one) were more exposed to $\mathrm{Co}, \mathrm{Cu}$ and $\mathrm{Sn}$ than benthic feeders (group three). This is suggested by the correlation found between $\mathrm{Co}$ and $\mathrm{Cu}$ and $\mathrm{n}-3$ PUFAs, which were dominant in group one. Indeed, $\mathrm{Cu}$ was positively correlated with DHA and Co with 22:5n-3, which is formed de novo from EPA. Co was also correlated with 20:4n-3, which can be used to characterise either fungi, protozoa or algae (Kharlamenko et al., 2001). In this case, it was present alongside the dinoflagellates marker DHA, suggesting a pelagic origin. Finally, diatom-feeding fish or their predators from group one accumulated more $\mathrm{Li}$ than other species. Contamination of this group by Li can also be linked to planktonic n-3 PUFAs 
(20:4n-3 and $22: 5 n-3)$ and to $18: 3 n-3$. The production of $18: 3 n-3$ from $18: 1 n-9$ is only realised by primary producers and requires delta 12 and delta 15 desaturase enzymes, respectively (Dalsgaard et al., 2003). Thus, primary producers (i.e. phytoplankton) seem to be particularly involved in Li transfer to the fish community.

Although not responsible for the differences among groups, some correlations between individual trophic markers and trace metals can give new insights into the determination of their origin near the coastline of Senegal (Tables 4 and 5).

In the Dakar fish community, Fe was positively correlated with $\delta^{15} \mathrm{~N}$, which suggests an increase with trophic level. This result is in accordance with the predominance of this element in the benthic predators group inferred by FAs. U was likewise correlated with 14:0, which is the dominant FA in marine cyanobacteria (Merritt et al., 1991; Carpenter et al., 1997) and suggests the benthic origin of this metal. In contrast, $\mathrm{Cu}$ and $\mathrm{Li}$ seemed to result from the consumption of pelagic organisms. Indeed, $\mathrm{Cu}$ was positively correlated with the diatoms marker EPA, and negatively with the nano- and picoplankton marker 18:1n-9, revealing dominance in the microphytoplankton. Moreover, Li was positively correlated with the planktonic 20:4n-3 and negatively with $\delta^{15} \mathrm{~N}$, which reveals a stronger presence in the lower trophic level species that feed on planktonic prey. It was also negatively correlated with 17:1n-8 and 18:2n-4, two FAs synthesised in large amounts by bacteria (Pond et al., 1997; Dalsgaard et al., 2003). Along with the results of the Li distribution in Casamance, it can be concluded that this element may be predominant in the pelagic environment

In Casamance, $\mathrm{Pb}$ was associated with the coastal/benthic isotope signature inferred by $\delta^{13} \mathrm{C}$ and 20:4n-6, which was likely the result of phytodetritus consumption. This corroborates observations in Dakar, which indicate that $\mathrm{Pb}$ may be derived from coastal anthropogenic sources (Diop et al., 2015). Cd and U were found to be associated with both the planktonic 
FA 22:5n-3 and a bottom linked FA: the bacterial FA 17:0 for Cd and the phytodetritus marker 22:4n-6 for U. Conversely, for observations in Dakar where these two elements had only a benthic origin, they seemed to result from a larger variety of sources in this case. Finally, Mn and Ni were only linked to n-3 PUFAs, which suggests a pelagic origin.

\subsection{Differences in accumulation patterns between communities}

Physiological characteristics, such as subcellular differences in handling metals (Eyckmans et al., 2012), can lead to differences in metal accumulation between species. However, even if only one species, C. rhonchus, was present in both of the stations sampled, general patterns can be drawn from the two fish communities.

In Dakar, among the 13 elements analysed, only two metals ( $\mathrm{Cu}$ and $\mathrm{Li}$ ) were only associated with planktonic markers, whereas eight of them (As, $\mathrm{Cd}, \mathrm{Co}, \mathrm{Fe}, \mathrm{Ni}, \mathrm{Pb}, \mathrm{Sn}$ and $\mathrm{Zn}$ ) were exclusively related to bacterial or phytodetritus/microphytobenthos markers (Table 6). As a result, the two species that generally accumulated more metals were the two benthic predators D. bellottii and P. prayensis. Concerning $\mathrm{Cd}, \mathrm{Ni}$ and $\mathrm{Pb}$, these results are in accordance with previous studies regarding the metallic contamination of sediments from the Dakar area and where high levels of these metals have been reported (Diop et al., 2012; Diagne et al., 2013; Diop et al., 2015). Furthermore, it is in accordance with the theory concerning the distribution of metals between the particulate and dissolved fraction. Indeed, $\mathrm{Co}$ and $\mathrm{Pb}$ are scavenged in greater amounts by the solid phase in the water column from the Dakar coast, which explains the fact that these elements sink to the sediments (Diop et al., 2014). Surprisingly, these authors also found high amounts of $\mathrm{Cr}$, whereas in this study, no correlation was established between this element and any marker. Even if extremely high concentrations have been reported in mussels from the harbour of Dakar (up to 298 ppm dry weight, Diagne et al., 2013), Cr showed the lowest affinity to the bioavailable fraction in sediments from this area 
among the other metals (Diop et al., 2015). The authors concluded that $\mathrm{Cr}$ cannot be remobilised into the aquatic environment under normal biogeochemical conditions, which could explain the low Cr levels observed in fish. Likewise, the sediments presented an elevated contamination of $\mathrm{Cu}$, whereas in the present study, it was associated with the pelagic environment. Finally, only Mn was found to correlate with the markers characteristic of both the pelagic and the benthic environment.

Because the Dakar area is exposed to urban and industrial rejects (Diop et al., 2012, 2014; Diop et al., 2015), the contamination may occur near the coast as shown for $\mathrm{Pb}$ with the stable isotope analysis (Fig. 4A). Thus, the trace metal elements may be rapidly trapped in the sediments, leading to a high contamination of benthic organisms in this region. For example, the mussel, Mytilus galloprovincialis, from Dakar is known to be highly contaminated with Cd (up to $8.5 \pm 2.8 \mathrm{ppm} \mathrm{dw}$ ) and $\mathrm{Pb}$ (up to $380 \pm 70.5 \mathrm{ppm} \mathrm{dw}$ ) (Diagne et al., 2013), and the other mussel species, Perna perna, also showed a greater amount of Cd (up to $7.55 \pm 1.65$ ppm dw) than in Morocco and Mauritania (Sidoumou et al., 2006; Diop et al., 2016). Finally, the two sand-living species, Cardita ajar and Dosinia isocardia, also presented very high levels of Cd (13.77 \pm 0.80 and $4.18 \pm 0.93$ respectively) (Sidoumou et al., 2006). Here, the sediment compartment seemed to be the major source for the transfer of metals up to the fish community.

Interestingly, in the Casamance region, metal concentration seems to be less dictated by the fish relationship with the sediments. Indeed, only $\mathrm{Pb}$ was exclusively related to microphytobenthos, whereas the other elements ( $\mathrm{Co}, \mathrm{Li}, \mathrm{Mn}$ and $\mathrm{Ni}$ ) were only associated with planktonic markers or both benthic and pelagic markers $(\mathrm{Cd}, \mathrm{Cu}, \mathrm{Fe}, \mathrm{U}$, and $\mathrm{Zn}$ ) (Table 6). Accordingly, the species with the lowest accumulation levels was in general the benthic fish G. decadactylus. The occurrence of metals is not likely to be the result of local anthropogenic inputs because this region is not subjected to industrial activities or heavy 
urban development. However, it may occur through fish migrations from another contaminated areas or the transport of elements by the hydrodynamic process. The Senegalese coast is subjected to wind-driven upwelling, which occurs mainly in winter and is stronger from February to April. It induces a coastal jet arising from the geostrophic adjustment of the surface density gradient between the cold upwelled coastal waters and the warmer open ocean waters (Allen, 1973). This upwelling jet is confined nearshore and flows southward alongside the coast of Senegal (Fig. 1) (Auger et al., 2015). Furthermore, recent studies have shown that the coastal waters of southern Senegal come from the upwelling area of Dakar Bay, around $200 \mathrm{~km}$ northernmost, through advection processes (Ndoye, 2016). Because the fish were collected during the active upwelling season when the coastal current is the strongest, it strengthens the hypothesis of a transport of the metals from the Dakar area subjected to industrial effluents of this region.

Finally, this study suggests that microphytoplankton (i.e., diatoms and dinoflagellates) were a more important source of accumulation than smaller size fraction species. Whereas nanoplankton are dominant in the phytoplankton community of the Dakar area, microplankton are the almost exclusive component in Casamance (Donval personal communication). As physical and biological factors seem to converge to induce a strong accumulation of trace metal elements in marine pelagic organisms in Casamance, further investigations are required to evaluate the impact of northern anthropogenic rejects in this region.

This case study of the coastal environment from Senegal showed that anthropogenic activities seemed to drive the input pathways of trace metal elements in the marine food webs. It also highlights the need to consider the trophic relationships to understand the accumulation patterns of the marine fish communities. 


\section{Conclusion}

This study demonstrated the implication of trophic ecology in the accumulation of several trace metal elements in fish communities. Stable isotopes (SIs) and fatty acids (FAs) were both relevant tools to discriminate trophic groups within the fish community, but FAs proved to be more discriminant to link metal contamination in fish with their trophic ecology. Because most previous studies trying to investigate metallic accumulation in the marine biota in relation to their trophic ecology used stable isotope analysis, we suggest that extending fatty acid analysis to heavy metal bioaccumulation studies would provide new perspectives.

In the region subjected to high anthropogenic metallic inputs, local rejects led to a higher accumulation in fish belonging to the benthic environment. In contrast, in the unaffected region, bioaccumulation was more associated with the pelagic ecosystem, where the metallic transfer to fish depended on the phytoplankton phylum on which the food web was based. This study suggests that microphytoplankton (i.e., diatoms and dinoflagellates) were a more important source of accumulation than nano- and picoplankton species.

In the present study, bioaccumulation was clearly dependent on the trophic preferences of fish, as inferred through SI signature and FA composition, for several trace metal elements. Moreover, fatty acids revealed many relationships between the dietary regimes and metal accumulation that were not visible with stable isotopes.

Acknowledgements: The authors thank greatly Sébastien Hervé for the design of the Fig. 1 and the graphical abstract, and Jean Raffray for the identification and the dissection of the fish. Samples used in this study were collected during a scientific cruise of the AWA project in West Africa. This article benefited from the comments of two anonymous reviewers. This work was financially supported by the French National Research Agency project ANR-11CEPL-0005 EPURE. 


\section{References}

Akadje, C., Diaby, M., Le Loc'h, F., Konan, J.K., N'da, K., 2013. Diet of the barracuda Sphyraena guachancho in Cote d'Ivoire (Equatorial Eastern Atlantic Ocean). Cybium 37, $285-293$.

Alfaro, A.C., Thomas, F., Sergent, L., Duxbury, M., 2006. Identification of trophic interactions within an estuarine food web (northern New Zealand) using fatty acid biomarkers and stable isotopes. Estuarine, Coastal and Shelf Science, Applying the Ecohydrology approach to the Guadiana estuary and coastal areas: lessons learned from dam impacted ecosystems 70, 271-286. doi:10.1016/j.ecss.2006.06.017

Allen, J.S., 1973. Upwelling and Coastal Jets in a Continuously Stratified Ocean. J. Phys. Oceanogr. 3, $245-257$. doi:10.1175/1520-0485(1973)003<0245:UACJIA $>2.0 . C O ; 2$

Auger, P.A., Machu, E., Gorgues, T., Grima, N., Waeles, M., 2015. Comparative study of potential transfer of natural and anthropogenic cadmium to plankton communities in the North-West African upwelling. Science of The Total Environment 505, 870-888. doi:10.1016/j.scitotenv.2014.10.045

Bachok, Z., Mfilinge, P.L., Tsuchiya, M., 2003. The diet of the mud clam Geloina coaxans (Mollusca, Bivalvia) as indicated by fatty acid markers in a subtropical mangrove forest of Okinawa, Japan. Journal of Experimental Marine Biology and Ecology 292, 187-197. doi:10.1016/S0022-0981(03)00160-6

Banaoui, A., Chiffoleau, J.-F., Moukrim, A., Burgeot, T., Kaaya, A., Auger, D., Rozuel, E., 2004. Trace metal distribution in the mussel Perna perna along the Moroccan coast. Mar. Pollut. Bull 48, 385-390. doi:10.1016/j.marpolbul.2003.11.007

Barhoumi, S., MESSAOUDI, I., DELI, T., SAÏD, K., KERKENI, A., 2009. Cadmium bioaccumulation in three benthic fish species, Salaria basilisca, Zosterisessor ophiocephalus and Solea vulgaris collected from the Gulf of Gabes in Tunisia. Journal of Environmental Sciences 21, 980-984. doi:10.1016/S10010742(08)62371-2

Beckmann, C.L., Mitchell, J.G., Stone, D.A.J., Huveneers, C., 2014. Inter-Tissue Differences in Fatty Acid Incorporation as a Result of Dietary Oil Manipulation in Port Jackson Sharks (Heterodontus portusjacksoni). Lipids 49, 577-590. doi:10.1007/s11745-014-3887-6

Berntssen, M.H.G., Aspholm, O.Ø., Hylland, K., Wendelaar Bonga, S.E., Lundebye, A.-K., 2001. Tissue metallothionein, apoptosis and cell proliferation responses in Atlantic salmon (Salmo salar L.) parr fed elevated dietary cadmium. Comparative Biochemistry and Physiology Part C: Toxicology \& Pharmacology 128, 299-310. doi:10.1016/S1532-0456(00)00204-0

Bodin, N., N’Gom-Kâ, R., Kâ, S., Thiaw, O.T., Tito de Morais, L., Le Loc’h, F., Rozuel-Chartier, E., Auger, D., Chiffoleau, J.-F., 2013. Assessment of trace metal contamination in mangrove ecosystems from Senegal, West Africa. Chemosphere 90, 150-157. doi:10.1016/j.chemosphere.2012.06.019

Boëly, T., Wysokinski, A., Elwertowski, J., 1973. Les chinchards des côtes sénégalaises et mauritaniennes : biologie - déplacements - ressources, Document Scientifique Provisoire. ORSTOM, Dakar.

Buchheister, A., Latour, R.J., 2010. Turnover and fractionation of carbon and nitrogen stable isotopes in tissues of a migratory coastal predator, summer flounder (Paralichthys dentatus). Can. J. Fish. Aquat. Sci. 67, 445-461. doi:10.1139/F09-196

Budge, S.M., Parrish, C.C., Mckenzie, C.H., 2001. Fatty acid composition of phytoplankton, settling particulate matter and sediments at a sheltered bivalve aquaculture site. Marine Chemistry 76, 285-303. doi:10.1016/S0304-4203(01)00068-8

Carpenter, E.J., Harvey, H.R., Fry, B., Capone, D.G., 1997. Biogeochemical tracers of the marine cyanobacterium Trichodesmium. Deep Sea Research Part I: Oceanographic Research Papers 44, $27-38$. doi:10.1016/S0967-0637(96)00091-X

Castro, J.J., 1993. Feeding ecology of chub mackerel Scomber japonicus in the Canary islands area. South African Journal of Marine Science 13, 323-328. doi:10.2989/025776193784287400

Caverivière, A., 1993. Les peuplements ichtyologiques démersaux : écologie et biologie, in: Le Loeuff, P., Marchal, E., Amon Kothias, J.B. (Eds.), Environnement et ressources aquatiques de Côte d'Ivoire : 1. Le milieu marin. ORSTOM, Paris, pp. 271-320.

Chahid, A., Hilali, M., Benlhachimi, A., Bouzid, T., 2014. Contents of cadmium, mercury and lead in fish from the Atlantic sea (Morocco) determined by atomic absorption spectrometry. Food Chemistry 147, 357360. doi:10.1016/j.foodchem.2013.10.008

Chavez, F.P., Messié, M., 2009. A comparison of Eastern Boundary Upwelling Ecosystems. Progress in Oceanography, Eastern Boundary Upwelling Ecosystems: Integrative and Comparative Approaches:Integrative and comparative approaches, 2-8 June 2008, Las Palmas, Gran Canaria, SpainEastern Boundary Upwelling Ecosystems Symposium 83, 80-96. doi:10.1016/j.pocean.2009.07.032

Chouvelon, T., Spitz, J., Caurant, F., Mèndez-Fernandez, P., Autier, J., Lassus-Débat, A., Chappuis, A., Bustamante, P., 2012. Enhanced bioaccumulation of mercury in deep-sea fauna from the Bay of Biscay (north-east Atlantic) in relation to trophic positions identified by analysis of carbon and nitrogen stable 
isotopes. Deep Sea Research Part I: Oceanographic Research Papers 65, 113-124.

doi:10.1016/j.dsr.2012.02.010

Cook, E.J., Bell, M.V., Black, K.D., Kelly, M.S., 2000. Fatty acid compositions of gonadal material and diets of the sea urchin, Psammechinus miliaris: trophic and nutritional implications. Journal of Experimental Marine Biology and Ecology 255, 261-274. doi:10.1016/S0022-0981(00)00301-4

Costalago, D., Navarro, J., Alvarez-Calleja, I., Palomera, I., 2012. Ontogenetic and seasonal changes in the feeding habits and trophic levels of two small pelagic fish species. Marine Ecology Progress Series 460, $169-181$.

Couturier, L.I.E., Rohner, C.A., Richardson, A.J., Marshall, A.D., Jaine, F.R.A., Bennett, M.B., Townsend, K.A., Weeks, S.J., Nichols, P.D., 2013. Stable Isotope and Signature Fatty Acid Analyses Suggest Reef Manta Rays Feed on Demersal Zooplankton. PLoS ONE 8, e77152. doi:10.1371/journal.pone.0077152

Dalsgaard, J., St. John, M., Kattner, G., Müller-Navarra, D., Hagen, W., 2003. Fatty acid trophic markers in the pelagic marine environment, in: Biology, B.-A. in M. (Ed.), . Academic Press, pp. 225-340.

Das, K., Lepoint, G., Loizeau, V., Debacker, V., Dauby, P., Bouquegneau, J.M., 2000. Tuna and Dolphin Associations in the North-east Atlantic: Evidence of Different Ecological Niches from Stable Isotope and Heavy Metal Measurements. Marine Pollution Bulletin 40, 102-109. doi:10.1016/S0025326X(99)00178-2

Derbal, P., Hichem Kara, M., 2008. Composition du régime alimentaire du bogue Boops boops (Sparidae) dans le golfe d'Annaba (Algérie). Cybium 32, 325-333.

Diagne, I., Ndiaye, M., Ndiaye, B., Diop, A., Thiom, M., 2013. Evaluation de la contamination métallique des moules Mytilus gallo provincialis et des sédiments marins au niveau des côtes de la région de Dakar (Sénégal). International Journal of Biological and Chemical Sciences 7, 872-883. doi:10.4314/ijbcs.v7i2.42

Diop, C., Dewaelé, D., Cazier, F., Diouf, A., Ouddane, B., 2015. Assessment of trace metals contamination level, bioavailability and toxicity in sediments from Dakar coast and Saint Louis estuary in Senegal, West Africa. Chemosphere. doi:10.1016/j.chemosphere.2014.12.041

Diop, C., Dewaelé, D., Diop, M., Touré, A., Cabral, M., Cazier, F., Fall, M., Diouf, A., Ouddane, B., 2014. Assessment of contamination, distribution and chemical speciation of trace metals in water column in the Dakar coast and the Saint Louis estuary from Senegal, West Africa. Marine Pollution Bulletin. doi:10.1016/j.marpolbul.2014.06.051

Diop, C., Dewaele, D., Toure, A., Cabral, M., Cazier, F., Fall, M., Ouddane, B., Diouf, A., 2012. Étude de la contamination par les éléments traces métalliques des sédiments cotiers au niveau des points d'évacuation des eaux usées à Dakar (Sénégal). Revue des sciences de l'eau 25, 277. doi:10.7202/1013107ar

Diop, M., Howsam, M., Diop, C., Cazier, F., Goossens, J.F., Diouf, A., Amara, R., 2016a. Spatial and seasonal variations of trace elements concentrations in liver and muscle of round Sardinelle (Sardinella aurita) and Senegalese sole (Solea senegalensis) along the Senegalese coast. Chemosphere 144, 758-766. doi:10.1016/j.chemosphere.2015.08.085

Diop, M., Howsam, M., Diop, C., Goossens, J.F., Diouf, A., Amara, R., 2016b. Assessment of trace element contamination and bioaccumulation in algae (Ulva lactuca), mussels (Perna perna), shrimp (Penaeus kerathurus), and fish (Mugil cephalus, Saratherondon melanotheron) along the Senegalese coast. Marine Pollution Bulletin 103, 339-343. doi:10.1016/j.marpolbul.2015.12.038

Diouf, P.S., 1996. Les peuplements de poissons des milieux estuariens de l'Afrique de l'Ouest : l'exemple de l'estuaire hyperhalin du Sine-Saloum. ORSTOM, Paris.

Domi, N., Bouquegneau, J.M., Das, K., 2005. Feeding ecology of five commercial shark species of the Celtic Sea through stable isotope and trace metal analysis. Marine Environmental Research 60, 551-569. doi:10.1016/j.marenvres.2005.03.001

Escribano, R., Pérez, C.S., 2010. Variability in fatty acids of two marine copepods upon changing food supply in the coastal upwelling zone off Chile: importance of the picoplankton and nanoplankton fractions. Journal of the Marine Biological Association of the United Kingdom 90, 301-313. doi:10.1017/S002531540999083X

Everaarts, J.M., Heesters, R., Fischer, C.V., 1993. Heavy metals (Cu, Zn, Pb, Cd) in sediment, zooplankton and epibenthic invertebrates from the area of the continental slope of the Banc d'Arguin (Mauritania). Hydrobiologia 258, 41-58. doi:10.1007/BF00006185

Eyckmans, M., Blust, R., De Boeck, G., 2012. Subcellular differences in handling Cu excess in three freshwater fish species contributes greatly to their differences in sensitivity to $\mathrm{Cu}$. Aquatic Toxicology 118-119, 97-107. doi:10.1016/j.aquatox.2012.03.019

Farias, I., Figueiredo, I., Janeiro, A.I., Bandarra, N.M., Batista, I., Morales-Nin, B., 2014. Reproductive and feeding spatial dynamics of the black scabbardfish, Aphanopus carbo Lowe, 1839, in NE Atlantic 
inferred from fatty acid and stable isotope analyses. Deep Sea Research Part I: Oceanographic Research Papers 89, 84-93. doi:10.1016/j.dsr.2014.04.010

Faye, D., Tito de Morais, L., Raffray, J., Sadio, O., Thiaw, O.T., Le Loc'h, F., 2011. Structure and seasonal variability of fish food webs in an estuarine tropical marine protected area (Senegal): Evidence from stable isotope analysis. Estuarine, Coastal and Shelf Science 92, 607-617. doi:10.1016/j.ecss.2011.02.017

Goutte, A., Cherel, Y., Churlaud, C., Ponthus, J.-P., Massé, G., Bustamante, P., 2015. Trace elements in Antarctic fish species and the influence of foraging habitats and dietary habits on mercury levels. Science of The Total Environment 538, 743-749. doi:10.1016/j.scitotenv.2015.08.103

Gutiérrez, M.H., Pantoja, S., Lange, C.B., 2012. Biogeochemical significance of fatty acid distribution in the coastal upwelling ecosystem off Concepción $\left(3^{\circ} \mathrm{S}\right)$, Chile. Organic Geochemistry 49, 56-67. doi:10.1016/j.orggeochem.2012.05.010

Horta, M., Costa, M.J., Cabral, H., 2004. Spatial and trophic niche overlap between Diplodus bellottii and Diplodus vulgaris in the Tagus estuary, Portugal. Journal of the Marine Biological Association of the United Kingdom 84, 837-842. doi:10.1017/S0025315404010033h

Jaschinski, S., Brepohl, D.C., Sommer, U., 2011. Seasonal variation in carbon sources of -mesograzers and small predators in an eelgrass community: stable isotope and fatty acid analyses. Mar Ecol Prog Ser 431, 6982. doi: $10.3354 /$ meps09143

Jasinski, S., 2015. Phosphate Rock, Mineral Commodity Summaries 2015. US Geological Survey.

Kattner, G., Hagen, W., 2009. Lipids in marine copepods: latitudinal characteristics and perspective to global warming, in: Kainz, M., Brett, M.T., Arts, M.T. (Eds.), Lipids in Aquatic Ecosystems. Springer New York, pp. 257-280.

Kelly, J.R., Scheibling, R.E., 2012. Fatty acids as dietary tracers in benthic food webs. Mar Ecol Prog Ser 446, 1-22. doi:10.3354/meps09559

Kelly, J.R., Scheibling, R.E., Iverson, S.J., 2009. Fatty acids tracers for native and invasive macroalgae in an experimental food web. Mar Ecol Prog Ser 391, 53-63. doi:10.3354/meps08234

Kharlamenko, V.I., Kiyashko, S.I., Imbs, A.B., Vyshkvartzev, D.I., 2001. Identification of food sources of invertebrates from the seagrass Zostera marina community using carbon and sulfur stable isotope ratio and fatty acid analyses. Mar Ecol Prog Ser 220, 103-117. doi:10.3354/meps220103

Kim, H., Gandhi, S.R., Moreau, R.A., Weete, J.D., 1998. Lipids of Haliphthoros philippinensis: An oomycetous marine microbe. J Amer Oil Chem Soc 75, 1657-1665. doi:10.1007/s11746-998-0108-6

Kim, S.G., Eom, K.-H., Kim, S.-S., Jin, H.-G., Kang, J.-C., 2006. Kinetics of Cd accumulation and elimination in tissues of juvenile rockfish (Sebastes schlegeli) exposed to dietary Cd. Marine Environmental Research 62, 327-340. doi:10.1016/j.marenvres.2006.05.001

Layman, C.A., Araujo, M.S., Boucek, R., Hammerschlag-Peyer, C.M., Harrison, E., Jud, Z.R., Matich, P., Rosenblatt, A.E., Vaudo, J.J., Yeager, L.A., Post, D.M., Bearhop, S., 2012. Applying stable isotopes to examine food-web structure: an overview of analytical tools. Biological Reviews 87, 545-562. doi:10.1111/j.1469-185X.2011.00208.x

Lee, R.F., Hagen, W., Kattner, G., 2006. Lipid storage in marine zooplankton. Mar Ecol Prog Ser 307, 273-306. doi: $10.3354 /$ meps 307273

Le Grand, F., Soudant, P., Siah, A., Tremblay, R., Marty, Y., Kraffe, E., 2014. Disseminated neoplasia in the soft-shell clam Mya arenaria: membrane lipid composition and functional parameters of circulating cells. Lipids 49, 807-818. doi:10.1007/s11745-014-3917-4

Metian, M., Warnau, M., Chouvelon, T., Pedraza, F., Rodriguez y Baena, A.M., Bustamante, P., 2013. Trace element bioaccumulation in reef fish from New Caledonia: Influence of trophic groups and risk assessment for consumers. Marine Environmental Research 87-88, 26-36. doi:10.1016/j.marenvres.2013.03.001

McMeans, B.C., Svavarsson, J., Dennard, S., Fisk, A.T., 2010. Diet and resource use among Greenland sharks (Somniosus microcephalus) and teleosts sampled in Icelandic waters, using $\delta 13 \mathrm{C}, \delta 15 \mathrm{~N}$, and mercury. Can. J. Fish. Aquat. Sci. 67, 1428-1438. doi:10.1139/F10-072

McMeans, B.C., Arts, M.T., Fisk, A.T., 2015. Impacts of food web structure and feeding behavior on mercury exposure in Greenland Sharks (Somniosus microcephalus). Science of The Total Environment, Special Issue: Mercury in Canada's North 509-510, 216-225. doi:10.1016/j.scitotenv.2014.01.128

Merritt, M.V., Rosenstein, S.P., Rachel, C.L., Chou, H., Allen, M.M., n.d. A comparison of the major lipid classes and fatty acid composition of marine unicellular cyanobacteria with freshwater species. Arch. Microbiol. 155, 107-113. doi:10.1007/BF00248602

Meziane, T., Tsuchiya, M., 2000. Fatty acids as tracers of organic matter in the sediment and food web of a mangrove/intertidal flat ecosystem, Okinawa, Japan. Mar Ecol Prog Ser 200, 49-57. doi:10.3354/meps200049 
Ndoye, S., 2016. Fonctionnement dynamique du centre d'upwelling sud-sénégalais : approche par la modélisation réaliste et l'analyse d'observations satellite de température de surface de la mer.

Njinkoué, J.-M., Barnathan, G., Miralles, J., Gaydou, E.-M., Samb, A., 2002. Lipids and fatty acids in muscle, liver and skin of three edible fish from the Senegalese coast: Sardinella maderensis, Sardinella aurita and Cephalopholis taeniops. Comparative Biochemistry and Physiology Part B: Biochemistry and Molecular Biology 131, 395-402. doi:10.1016/S1096-4959(01)00506-1

Ofukany, A.F.A., Wassenaar, L.I., Bond, A.L., Hobson, K.A., 2014. Defining fish community structure in Lake Winnipeg using stable isotopes $(\delta 13 \mathrm{C}, \delta 15 \mathrm{~N}, \delta 34 \mathrm{~S})$ : Implications for monitoring ecological responses and trophodynamics of mercury \& other trace elements. Science of The Total Environment 497-498, 239-249. doi:10.1016/j.scitotenv.2014.07.125

Parrish, C.C., Abrajano, T.A., Budge, S.M., Helleur, R.J., Hudson, E.D., Pulchan, K., Ramos, C., 2000. Lipid and Phenolic Biomarkers in Marine Ecosystems: Analysis and Applications, in: Wangersky, P.J. (Ed.), Marine Chemistry, The Handbook of Environmental Chemistry. Springer Berlin Heidelberg, pp. 193223.

Pethybridge, H., Bodin, N., ArsenaultPernet, E.J., Bourdeix, J.H., Brisset, B., Bigot, J.L., Roos, D., Peter, M., 2014. Temporal and inter-specific variations in forage fish feeding conditions in the NW Mediterranean: lipid content and fatty acid compositional changes. Mar Ecol Prog Ser 512, 39-54. doi:10.3354/meps 10864

Pethybridge, H., Butler, E.C.V., Cossa, D., Daley, R., Boudou, A., 2012. Trophic structure and biomagnification of mercury in an assemblage of deepwater chondrichthyans from southeastern Australia. Mar Ecol Prog Ser 451, 163-174. doi:10.3354/meps09593

Pond, D.W., Dixon, D.R., Bell, M.V., Fallick, A.E., Sargent, J.R., 1997. Occurrence of 16:2(n-4) and 18:2(n-4) fatty acids in the lipids of the hydrothermal vent shrimps Rimicaris exoculata and Alvinocaris markensis:nutritional and trophic implications. Mar Ecol Prog Ser 156, 167-174. doi:10.3354/meps 156167

Post, D.M., Layman, C.A., Arrington, D.A., Takimoto, G., Quattrochi, J., Montaña, C.G., 2007. Getting to the fat of the matter: models, methods and assumptions for dealing with lipids in stable isotope analyses. Oecologia 152, 179-189. doi:10.1007/s00442-006-0630-X

Rajendran, N., Matsuda, O., Imamura, N., Urushigawa, Y., 1992. Variation in Microbial Biomass and Community Structure in Sediments of Eutrophic Bays as Determined by Phospholipid Ester-Linked Fatty Acids. Appl. Environ. Microbiol. 58, 562-571.

Rajendran, N., Suwa, Y., Urushigawa, Y., 1993. Distribution of phospholipid ester-linked fatty acid biomarkers for bacteria in the sediment of Ise Bay, Japan. Marine Chemistry 42, 39-56.

Richoux, N.B., Froneman, P.W., 2008. Trophic ecology of dominant zooplankton and macrofauna in a temperate, oligotrophic South African estuary: a fatty acid approach. Mar Ecol Prog Ser 357, 121-137. doi:10.3354/meps07323

Roméo, M., Siau, Y., Sidoumou, Z., Gnassia-Barelli, M., 1999. Heavy metal distribution in different fish species from the Mauritania coast. The Science of The Total Environment 232, 169-175. doi:10.1016/S00489697(99)00099-6

Schukat, A., Auel, H., Teuber, L., Lahajnar, N., Hagen, W., 2014. Complex trophic interactions of calanoid copepods in the Benguela upwelling system. Journal of Sea Research 85, 186-196. doi:10.1016/j.seares.2013.04.018

Sidoumou, Z., Gnassia-Barelli, M., Siau, Y., Morton, V., Roméo, M., 2006. Heavy metal concentrations in molluscs from the Senegal coast. Environment International 32, 384-387. doi:10.1016/j.envint.2005.09.001

Sidoumou, Z., Gnassia-Barelli, M., Siau, Y., Morton, V., Roméo, M., 2005. Distribution and Concentration of Trace Metals in Tissues of Different Fish Species from the Atlantic Coast of Western Africa. Bulletin of Environmental Contamination and Toxicology 74, 988-995. doi:10.1007/s00128-005-0677-0

Sidoumou, Z., Gnassia-Barelli, M., Siau, Y., Romeo, M., 1999. Study of heavy metals in two species of molluscs from the Mauritania coast, Crassostrea gigas and Perna perna. Journal de recherche oceanographique. Paris 24, 13-18.

Siscar, R., Torreblanca, A., del Ramo, J., Solé, M., 2014. Modulation of metallothionein and metal partitioning in liver and kidney of Solea senegalensis after long-term acclimation to two environmental temperatures. Environmental Research 132, 197-205. doi:10.1016/j.envres.2014.04.020

Siscar, R., Torreblanca, A., Palanques, A., Solé, M., 2013. Metal concentrations and detoxification mechanisms in Solea solea and Solea senegalensis from NW Mediterranean fishing grounds. Marine Pollution Bulletin 77, 90-99. doi:10.1016/j.marpolbul.2013.10.026

Sley, A., Jarboui, O., Ghorbel, M., Bouain, A., 2008. Diet composition and food habits of Caranx rhonchus (Carangidae) from the Gulf of Gabes (central Mediterranean). Journal of the Marine Biological Association of the United Kingdom 88, 831-836. doi:10.1017/S0025315408001379 
Soudant, P., Moal, J., Marty, Y., Samain, J.F., 1996. Impact of the quality of dietary fatty acids on metabolism and the composition of polar lipid classes in female gonads of Pecten maximus (L.). Journal of Experimental Marine Biology and Ecology 205, 149-163. doi:10.1016/S0022-0981(96)02608-1

Stowasser, G., McAllen, R., Pierce, G.J., Collins, M.A., Moffat, C.F., Priede, I.G., Pond, D.W., 2009. Trophic position of deep-sea fish-Assessment through fatty acid and stable isotope analyses. Deep Sea Research Part I: Oceanographic Research Papers 56, 812-826. doi:10.1016/j.dsr.2008.12.016

Stowasser, G., Pond, D.W., Collins, M.A., 2012. Fatty acid trophic markers elucidate resource partitioning within the demersal fish community of South Georgia and Shag Rocks (Southern Ocean). Marine Biology 159, 2299-2310. doi:10.1007/s00227-012-2015-5

Teuber, L., Schukat, A., Hagen, W., Auel, H., 2014. Trophic interactions and life strategies of epi- to bathypelagic calanoid copepods in the tropical Atlantic Ocean. J. Plankton Res. 36, 1109-1123. doi:10.1093/plankt/fbu030

Twining, B.S., Baines, S.B., 2013. The Trace Metal Composition of Marine Phytoplankton. Annual Review of Marine Science 5, 191-215. doi:10.1146/annurev-marine-121211-172322

Twining, B.S., Rauschenberg, S., Morton, P.L., Vogt, S., 2015. Metal contents of phytoplankton and labile particulate material in the North Atlantic Ocean. Progress in Oceanography 137, Part A, 261-283. doi:10.1016/j.pocean.2015.07.001

Valiela, I., 2015. Food Web Structure and Its Controls I, in: Marine Ecological Processes. Springer New York, pp. 311-355.

Volkman, J.K., Johns, R.B., Gillan, F.T., Perry, G.J., Bavor Jr, H.J., 1980. Microbial lipids of an intertidal sediment-I. Fatty acids and hydrocarbons. Geochimica et Cosmochimica Acta 44, 1133-1143. doi:10.1016/0016-7037(80)90067-8 
Figures

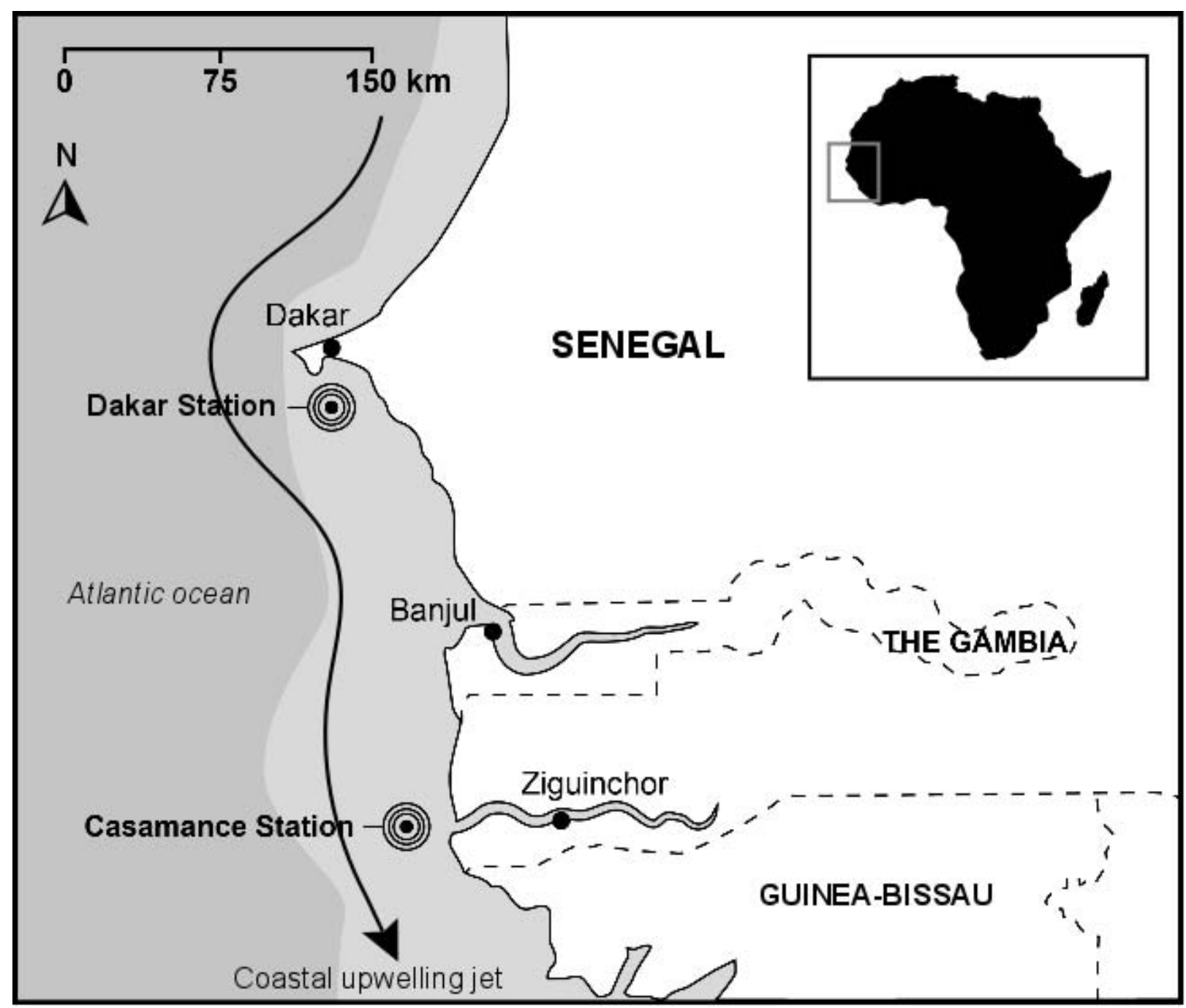

Figure 1 A map showing the two sample stations along the coast of Senegal. 
A

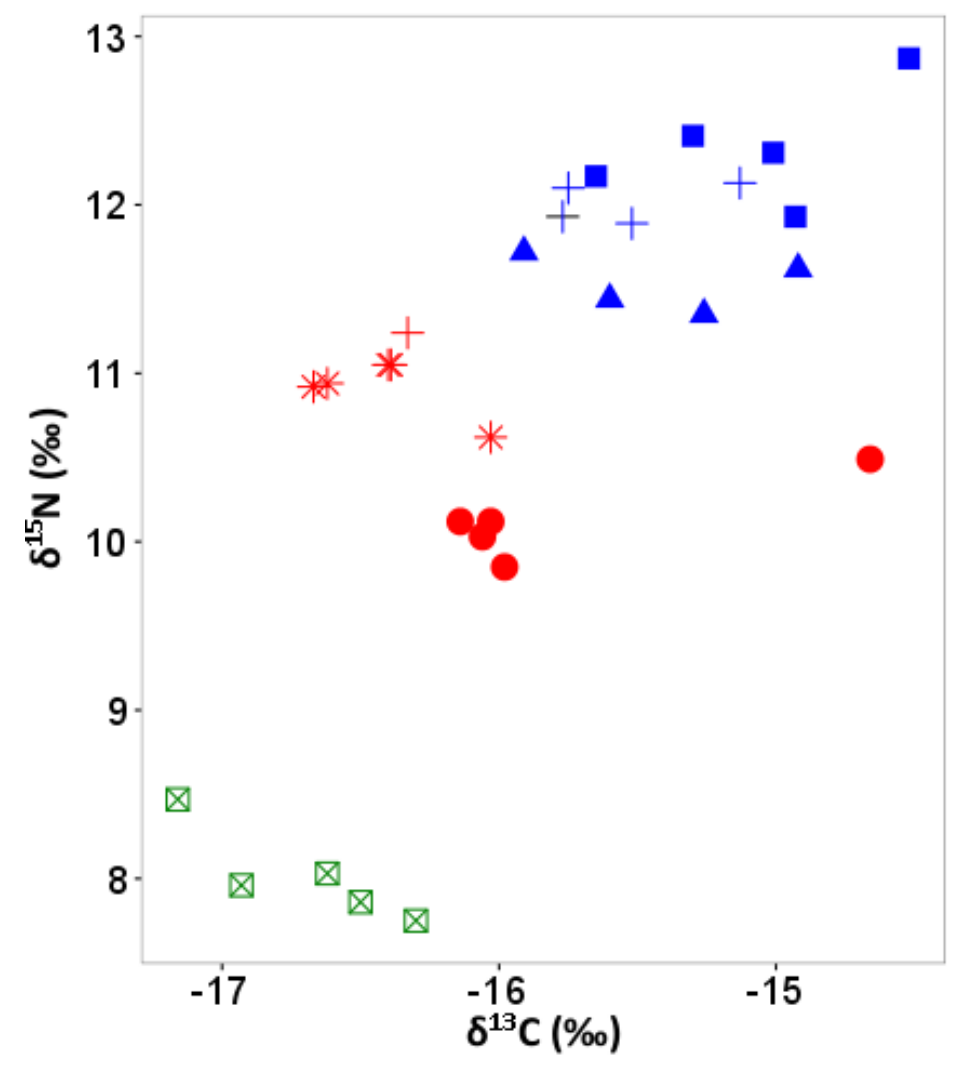

B

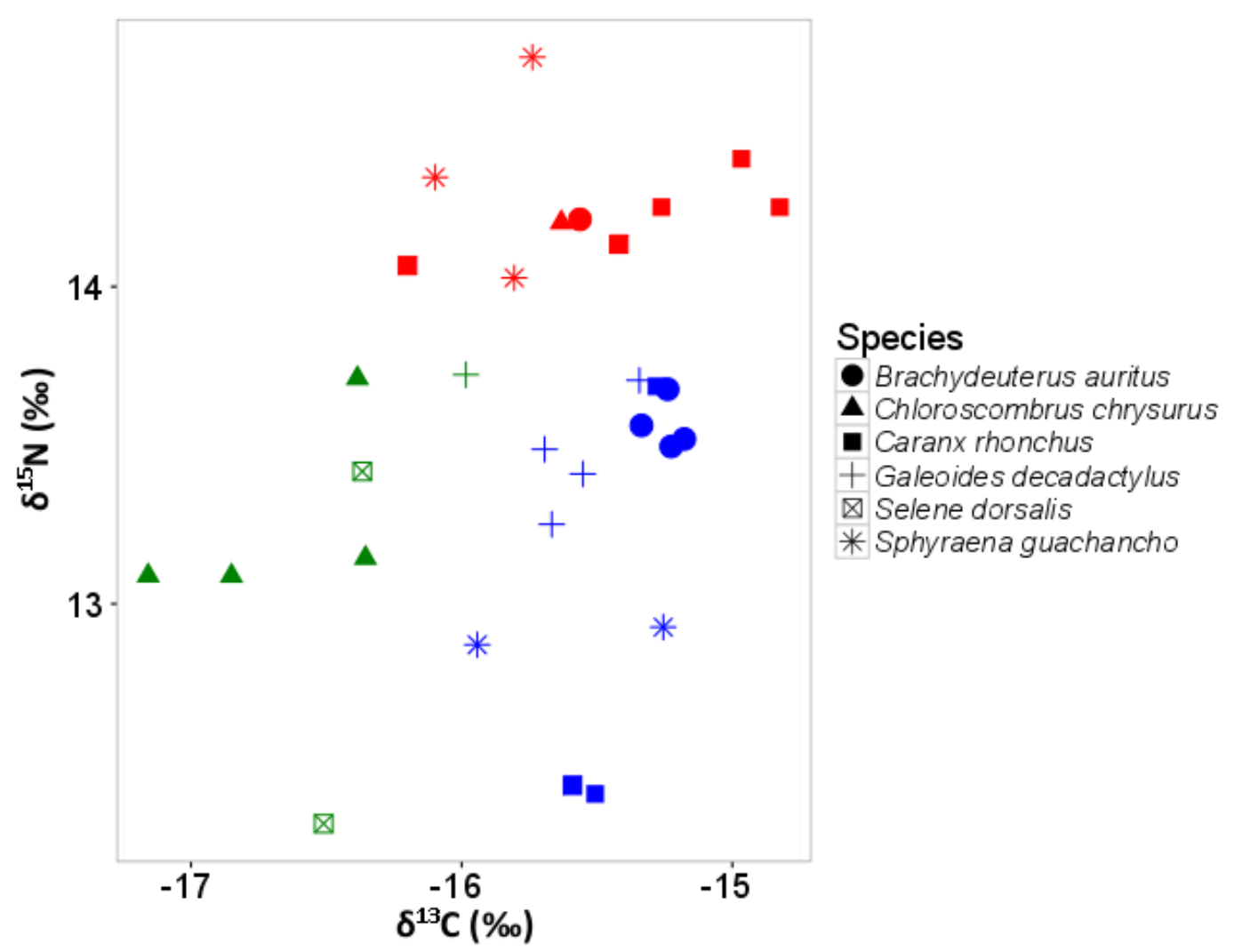

Figure 2 Muscle $\delta 13 \mathrm{C}$ and $\delta 15 \mathrm{~N}$ values (\%o) of individuals from six species from Dakar (A) and from Casamance (B). The groups were derived from the result of a hierarchical cluster analysis (Ward's method). Group one is shown in green, group two in red and group three in blue in each region. 
A

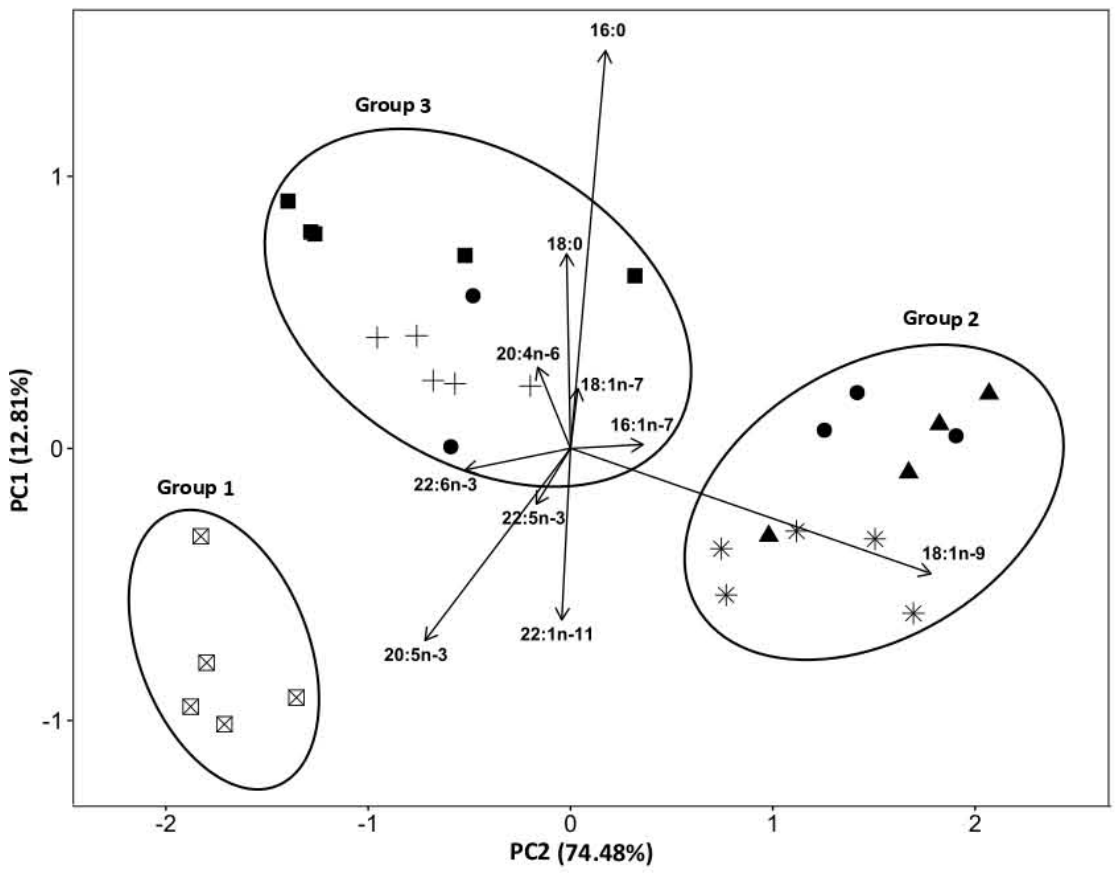

B

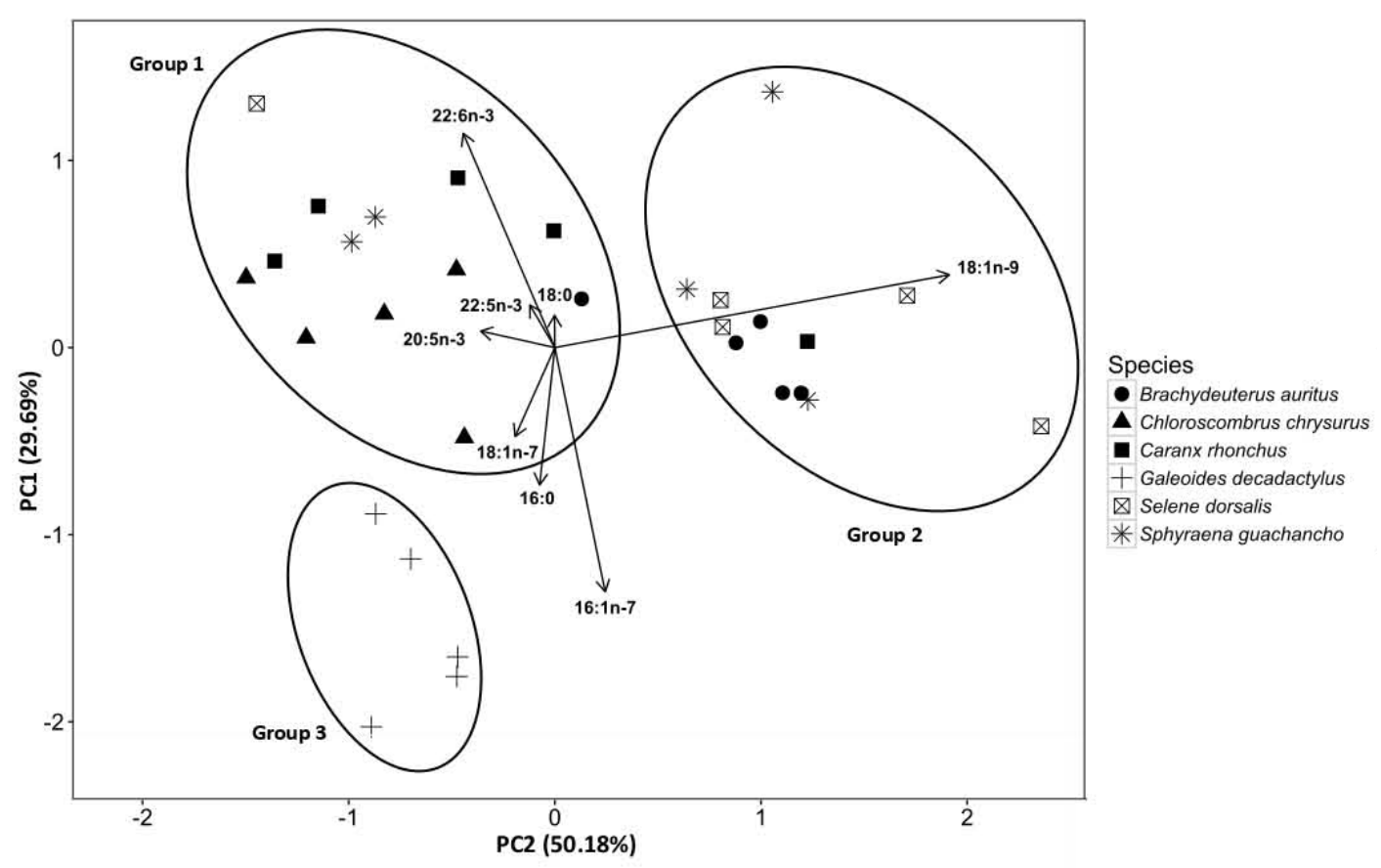

Figure 3 Principal component analysis (PCA) of the fatty acid composition of the liver of six fish species from Dakar (A) and from Casamance (B). The trophic groups (circled) were derived from the result of a hierarchical cluster analysis (Ward's clustering method). Fatty acids that account for more than $75 \%$ of the contribution of dissimilarity between the groups in the similarity of percentages analysis (SIMPER) are shown. 
A

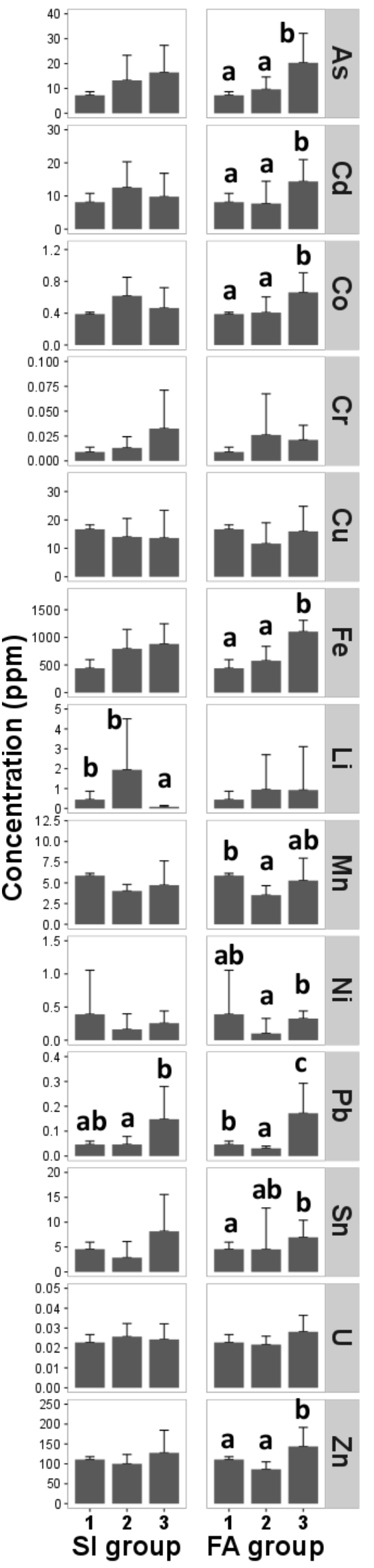

B

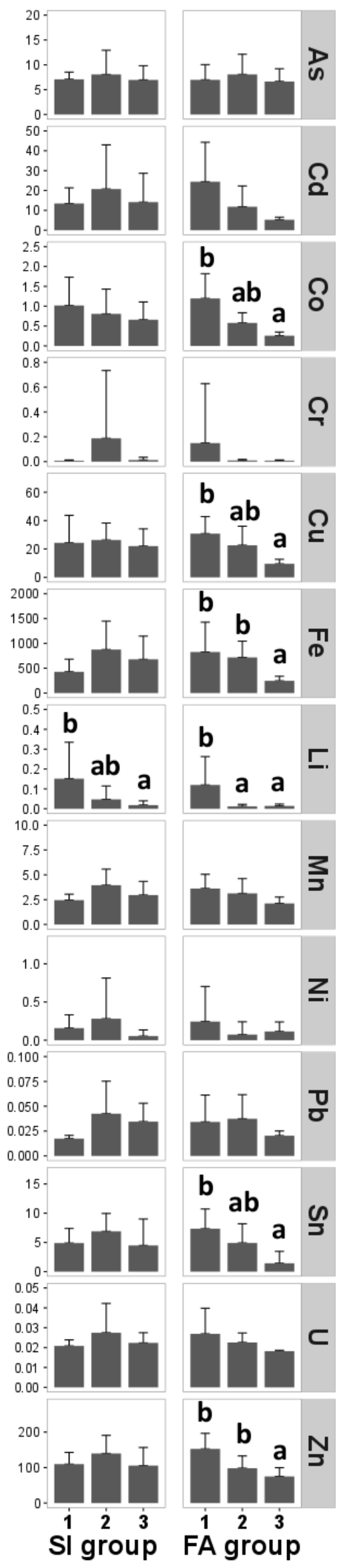


Figure 4 Comparison of the trace element concentrations $\left(\mu \mathrm{g} \cdot \mathrm{g}^{-1}\right.$ dry wt) in the liver of fish from Dakar (A) and from Casamance (B) according to their trophic group. SI group: trophic groups inferred by stable isotopes; FA group: trophic groups inferred by fatty acids. In each region, FA groups one and two included fish feeding mostly on pelagic prey, whereas FA group three contained fish feeding mostly on benthic prey. Different letters indicate significant differences between groups (ANOVAs followed by Tukey's HSD tests or KW tests followed by multiple comparison tests). 


\section{Tables}

Table 1 Summary (mean \pm standard deviation) of the biological parameters of fish from Dakar and Casamance. TL: trophic level (Froese and Pauly, 2016); n: number of individuals; Total length in $\mathrm{cm}$; Wet weight in $\mathrm{g}$.

\begin{tabular}{|c|c|c|c|c|c|c|}
\hline Station & Family & Species & TL & $\mathbf{n}$ & Total length (cm) & Wet weight \\
\hline Dakar & Sparidae & Boops boops & 3 & 5 & $18.7 \pm 1.6$ & $63.7 \pm 2.2$ \\
& Carangidae & Caranx rhonchus & 3.6 & 4 & $19.9 \pm 1.4$ & $91.3 \pm 13.1$ \\
& Sparidae & Diplodus bellottii & 3.5 & 5 & $21.1 \pm 1.8$ & $77.9 \pm 8.7$ \\
& Mullidae & Pseudupeneus prayensis & 3.2 & 5 & $21.4 \pm 1.1$ & $120.6 \pm 15.0$ \\
& Scombridae & Scomber japonicus & 3.4 & 5 & $16.2 \pm 0.6$ & $32.9 \pm 5.2$ \\
& Carangidae & Trachurus trecae & 3.5 & 5 & $21.8 \pm 0.4$ & $100.0 \pm 4.8$ \\
\hline Casamance & Haemulidae & Brachydeuterus auritus & 3 & 5 & $20.8 \pm 0.4$ & $127.0 \pm 5.0$ \\
& Carangidae & Chloroscombrus chrysurus & 3.5 & 5 & $20.3 \pm 1.2$ & $72.2 \pm 10.6$ \\
& Carangidae & Caranx rhonchus & 3.6 & 5 & $32.9 \pm 3.0$ & $334.4 \pm 68.8$ \\
& Polynemidae & Galeoides decadactylus & 3.6 & 5 & $17.6 \pm 1.3$ & $63.0 \pm 16.1$ \\
& Carangidae & Selene dorsalis & 4.1 & 5 & $24.4 \pm 1.3$ & $170.0 \pm 22.7$ \\
& Sphyraenidae & Sphyraena guachancho & 4.4 & 5 & $34.4 \pm 3.3$ & $197.0 \pm 53.6$ \\
\hline
\end{tabular}


Table 2 Fatty acid composition (mean \pm SD, \%) of liver tissue of the three groups derived from the result of a hierarchical cluster analysis (Ward's method) from Dakar. Only FAs accounting for $\geq 0.5 \%$ of total FA in at least one fish sample are shown. Different letters indicate significant differences between the groups (ANOVAs followed by Tukey's HSD tests or KW tests followed by multiple comparison tests).

\begin{tabular}{|c|c|c|c|}
\hline \multirow[b]{2}{*}{ FA } & \multicolumn{3}{|c|}{ Group } \\
\hline & 1 & 2 & 3 \\
\hline TMTD & $0.5 \pm 0.2^{b}$ & $0.2 \pm 0.1^{\mathrm{a}}$ & $0.2 \pm 0.1^{\mathrm{a}}$ \\
\hline iso17:0 & $0.5 \pm 0.2^{\mathrm{a}}$ & $0.4 \pm 0.1^{\mathrm{b}}$ & $1.1 \pm 0.5^{\mathrm{a}}$ \\
\hline ant17:0 & $0.1 \pm 0.0^{\mathrm{a}}$ & $0.1 \pm 0.0^{\mathrm{a}}$ & $0.3 \pm 0.2^{b}$ \\
\hline 14:0 & $2.8 \pm 0.6$ & $2.8 \pm 0.7$ & $2.7 \pm 1.8$ \\
\hline $15: 0$ & $0.3 \pm 0.1^{\mathrm{a}}$ & $0.2 \pm 0.1^{\mathrm{b}}$ & $0.7 \pm 0.2^{\mathrm{c}}$ \\
\hline $16: 0$ & $14.5 \pm 1.5^{b}$ & $20.5 \pm 2.3^{\mathrm{a}}$ & $22.7 \pm 1.4^{\mathrm{a}}$ \\
\hline $17: 0$ & $0.9 \pm 0.0^{\mathrm{a}}$ & $0.4 \pm 0.1^{\mathrm{b}}$ & $1.3 \pm 0.5^{\mathrm{a}}$ \\
\hline 18:0 & $4.3 \pm 1.0^{\mathrm{a}}$ & $6.0 \pm 0.9^{\mathrm{a}}$ & $7.9 \pm 1.7^{b}$ \\
\hline$\sum$ SFA & $23.9 \pm 1.6^{\mathrm{a}}$ & $\mathbf{3 0} \pm 2.5^{\mathrm{b}}$ & $\mathbf{3 6 . 8} \pm 4.0^{\mathrm{c}}$ \\
\hline $16: 1 n-7$ & $5.1 \pm 1.2^{\mathrm{a}}$ & $8.6 \pm 3.0^{b}$ & $5.9 \pm 2.4^{\mathrm{a}}$ \\
\hline $17: 1 \mathrm{n}-8$ & $0.3 \pm 0.3^{\mathrm{a}}$ & $0.3 \pm 0.1^{\mathrm{ab}}$ & $0.5 \pm 0.2^{b}$ \\
\hline $18: 1 n-11$ & $0.9 \pm 0.6^{\mathrm{a}}$ & $0.0 \pm 0.0^{\mathrm{b}}$ & $0.2 \pm 0.1^{\mathrm{a}}$ \\
\hline $18: 1 n-9$ & $3.8 \pm 1.2^{\mathrm{a}}$ & $24.9 \pm 3.1^{\mathrm{b}}$ & $8.5 \pm 3.3^{c}$ \\
\hline $18: 1 \mathrm{n}-7$ & $3.0 \pm 0.5^{\mathrm{a}}$ & $4.0 \pm 1.0^{\mathrm{ab}}$ & $4.6 \pm 1.0^{b}$ \\
\hline $20: 1 n-9$ & $1.8 \pm 0.6^{\mathrm{a}}$ & $1.4 \pm 0.9^{\mathrm{ab}}$ & $0.6 \pm 0.5^{b}$ \\
\hline $22: 1 n-11$ & $3.4 \pm 1.6^{\mathrm{a}}$ & $1.6 \pm 1.7^{\mathrm{a}}$ & $0.3 \pm 0.6^{b}$ \\
\hline $22: 1 n-9$ & $0.5 \pm 0.2^{\mathrm{b}}$ & $0.2 \pm 0.1^{\mathrm{a}}$ & $0.2 \pm 0.1^{\mathrm{a}}$ \\
\hline$\sum$ MUFA & $18.7 \pm 3.6^{\mathrm{a}}$ & $41.1 \pm 3.9^{b}$ & $\mathbf{2 0 . 8} \pm 5.4^{\mathrm{a}}$ \\
\hline $16: 2 n-4$ & $0.5 \pm 0.2$ & $0.3 \pm 0.2$ & $0.2 \pm 0.1$ \\
\hline $16: 3 n-4$ & $0.4 \pm 0.3$ & $0.4 \pm 0.2$ & $0.2 \pm 0.1$ \\
\hline $16: 3 n-6$ & $0.2 \pm 0.0$ & $0.1 \pm 0.1$ & $0.4 \pm 0.5$ \\
\hline $16: 4 n-1$ & $0.8 \pm 0.3^{\mathrm{a}}$ & $0.5 \pm 0.3^{\mathrm{a}}$ & $0.2 \pm 0.1^{b}$ \\
\hline $18: 2 n-6$ & $0.6 \pm 0.1$ & $0.5 \pm 0.1$ & $0.7 \pm 0.2$ \\
\hline $18: 2 n-4$ & $0.5 \pm 0.1^{\mathrm{a}}$ & $0.3 \pm 0.1^{\mathrm{b}}$ & $0.4 \pm 0.1^{\mathrm{a}}$ \\
\hline $18: 3 n-4$ & $0.5 \pm 0.2$ & $0.4 \pm 0.1$ & $0.4 \pm 0.1$ \\
\hline $18: 3 n-3$ & $0.6 \pm 0.1^{\mathrm{a}}$ & $0.4 \pm 0.2^{\mathrm{b}}$ & $0.3 \pm 0.1^{b}$ \\
\hline $18: 4 n-3$ & $1.0 \pm 0.2^{\mathrm{a}}$ & $0.8 \pm 0.3^{\mathrm{a}}$ & $0.5 \pm 0.2^{b}$ \\
\hline $18: 5 n-3$ & $1.3 \pm 0.7^{\mathrm{b}}$ & $0.4 \pm 0.3^{\mathrm{a}}$ & $0.3 \pm 0.1^{\mathrm{a}}$ \\
\hline $20: 4 n-6$ & $2.0 \pm 1.1^{\mathrm{a}}$ & $0.8 \pm 0.2^{\mathrm{b}}$ & $2.9 \pm 0.8^{\mathrm{a}}$ \\
\hline $20: 4 n-3$ & $1.2 \pm 0.2^{\mathrm{b}}$ & $0.7 \pm 0.2^{\mathrm{a}}$ & $0.7 \pm 0.2^{\mathrm{a}}$ \\
\hline $20: 5 n-3$ & $20.0 \pm 1.5^{\mathrm{a}}$ & $9.2 \pm 1.4^{\mathrm{b}}$ & $13.3 \pm 2.3^{\mathrm{c}}$ \\
\hline $21: 5 n-3$ & $0.7 \pm 0.3$ & $0.5 \pm 0.2$ & $0.4 \pm 0.1$ \\
\hline $22: 4 n-6$ & $0.5 \pm 0.3^{\mathrm{a}}$ & $0.2 \pm 0.1^{\mathrm{b}}$ & $0.7 \pm 0.3^{\mathrm{a}}$ \\
\hline $22: 5 n-6$ & $0.3 \pm 0.2^{\mathrm{a}}$ & $0.2 \pm 0.1^{\mathrm{b}}$ & $0.6 \pm 0.2^{\mathrm{c}}$ \\
\hline $22: 5 n-3$ & $4.9 \pm 1.2^{\mathrm{a}}$ & $2.3 \pm 0.6^{\mathrm{b}}$ & $3.1 \pm 0.6^{\mathrm{c}}$ \\
\hline $22: 6 n-3$ & $14.2 \pm 4.2^{\mathrm{a}}$ & $7.5 \pm 1.6^{\mathrm{b}}$ & $11.1 \pm 3.3^{\mathrm{a}}$ \\
\hline$\sum$ PUFA & $\mathbf{5 0 . 4} \pm 3.0^{\mathrm{a}}$ & $25.2 \pm 4.0^{\mathrm{b}}$ & $36.4 \pm 5.4^{\mathrm{c}}$ \\
\hline$\sum$ BAFA & $1.8 \pm 0.1^{\mathrm{a}}$ & $1.0 \pm 0.2^{\mathrm{b}}$ & $3.4 \pm 1.0^{\mathrm{c}}$ \\
\hline$\sum \mathbf{n}-\mathbf{3}$ & $55.4 \pm 4.0^{\mathrm{b}}$ & $33.22 \pm 6.7^{\mathrm{a}}$ & $37.8 \pm 3.9^{\mathrm{a}}$ \\
\hline$\sum n-6$ & $3.7 \pm 1.7^{\mathrm{a}}$ & $1.7 \pm 0.3^{\mathrm{b}}$ & $5.3 \pm 1.3^{\mathrm{a}}$ \\
\hline $20: 5 n-3 / 22: 6 n-3$ & 1.4 & 1.2 & 1.2 \\
\hline
\end{tabular}


Table 3 Fatty acid composition (mean \pm SD, \%) of liver tissue of the three groups derived from the result of a hierarchical cluster analysis (Ward's method) from Casamance. Only FAs accounting for $\geq 0.5 \%$ of total FA in at least one fish sample are shown. Different letters indicate significant differences between groups (ANOVAs followed by Tukey's HSD tests or $\mathrm{KW}$ tests followed by multiple comparison tests).

\begin{tabular}{|c|c|c|c|}
\hline \multirow[b]{2}{*}{ FA } & \multicolumn{3}{|c|}{ Group } \\
\hline & 1 & 2 & 3 \\
\hline iso17:0 & $0.6 \pm 0.2^{\mathrm{a}}$ & $0.2 \pm 0.2^{b}$ & $0.7 \pm 0.2^{\mathrm{a}}$ \\
\hline $14: 0$ & $1.9 \pm 1.2^{\mathrm{a}}$ & $1.7 \pm 0.5^{\mathrm{a}}$ & $4.0 \pm 1.0^{\mathrm{b}}$ \\
\hline $15: 0$ & $0.4 \pm 0.2^{\mathrm{a}}$ & $0.2 \pm 0.1^{\mathrm{b}}$ & $0.3 \pm 0.0^{\mathrm{a}}$ \\
\hline $16: 0$ & $19.7 \pm 4.2$ & $19.2 \pm 4.0$ & $23.8 \pm 4.6$ \\
\hline $17: 0$ & $0.7 \pm 0.3^{b}$ & $0.3 \pm 0.1^{\mathrm{a}}$ & $0.4 \pm 0.1^{\mathrm{a}}$ \\
\hline $18: 0$ & $6.4 \pm 2.1^{\mathrm{a}}$ & $5.8 \pm 1.2^{\mathrm{ab}}$ & $4.5 \pm 0.5^{b}$ \\
\hline$\sum$ SFA & $\mathbf{2 9 . 8} \pm 6.8$ & $27.4 \pm 4.7$ & $33.7 \pm 5.5$ \\
\hline $14: 1 n-5$ & $0.1 \pm 0.1^{\mathrm{a}}$ & $0.2 \pm 0.3^{\mathrm{ab}}$ & $0.5 \pm 0.2^{b}$ \\
\hline $16: 1 n-13 t$ & $0.1 \pm 0.1$ & $0.1 \pm 0.2$ & $0.1 \pm 0.0$ \\
\hline $16: 1 n-9$ & $0.4 \pm 0.2$ & $0.5 \pm 0.4$ & $0.3 \pm 0.1$ \\
\hline $16: 1 \mathrm{n}-7$ & $6.1 \pm 2.6^{\mathrm{a}}$ & $10.3 \pm 3.7^{\mathrm{b}}$ & $16.3 \pm 3.5^{\mathrm{c}}$ \\
\hline $16: 1 n-5$ & $0.2 \pm 0.1^{\mathrm{a}}$ & $0.1 \pm 0.1^{\mathrm{a}}$ & $0.7 \pm 0.1^{\mathrm{b}}$ \\
\hline $17: 1 \mathrm{n}-8$ & $0.5 \pm 0.2$ & $0.4 \pm 0.1$ & $0.5 \pm 0.1$ \\
\hline $18: 1 n-9$ & $13.4 \pm 4.1^{\mathrm{a}}$ & $28.0 \pm 3.4^{\mathrm{b}}$ & $11.5 \pm 1.6^{\mathrm{a}}$ \\
\hline $18: 1 \mathrm{n}-7$ & $4.2 \pm 0.8^{\mathrm{a}}$ & $3.8 \pm 1.0^{\mathrm{a}}$ & $9.9 \pm 2.2^{b}$ \\
\hline $20: 1 n-9$ & $1.0 \pm 0.3^{\mathrm{a}}$ & $0.8 \pm 0.3^{\mathrm{ab}}$ & $0.5 \pm 0.1^{\mathrm{b}}$ \\
\hline $20: 1 n-7$ & $0.3 \pm 0.1^{\mathrm{a}}$ & $0.2 \pm 0.1^{\mathrm{a}}$ & $0.5 \pm 0.1^{\mathrm{b}}$ \\
\hline $22: 1 n-11$ & $0.5 \pm 0.4$ & $0.4 \pm 0.4$ & $0.2 \pm 0.1$ \\
\hline$\sum$ MUFA & $26.7 \pm 5.5^{\mathrm{a}}$ & $45.0 \pm 4.7^{b}$ & $41 \pm 1.6^{b}$ \\
\hline $16: 2 n-4$ & $0.3 \pm 0.2$ & $0.2 \pm 0.1$ & $0.1 \pm 0.0$ \\
\hline $16: 3 n-4$ & $0.2 \pm 0.2$ & $0.1 \pm 0.1$ & $0.2 \pm 0.1$ \\
\hline $16: 4 n-3$ & $0.2 \pm 0.1^{\mathrm{a}}$ & $0.1 \pm 0.0^{b}$ & $0.2 \pm 0.2^{\mathrm{ab}}$ \\
\hline $16: 4 n-1$ & $0.2 \pm 0.1^{\mathrm{a}}$ & $0.1 \pm 0.1^{\mathrm{b}}$ & $0.1 \pm 0.0^{\mathrm{ab}}$ \\
\hline $18: 2 n-9$ & $0.1 \pm 0.1^{\mathrm{a}}$ & $0.6 \pm 0.4^{b}$ & $0.2 \pm 0.1^{\mathrm{ab}}$ \\
\hline $18: 2 n-6$ & $1.3 \pm 0.3^{b}$ & $0.6 \pm 0.3^{\mathrm{a}}$ & $0.7 \pm 0.1^{\mathrm{a}}$ \\
\hline $18: 3 n-4$ & $0.3 \pm 0.1^{\mathrm{a}}$ & $0.2 \pm 0.1^{\mathrm{b}}$ & $0.2 \pm 0.1^{\mathrm{ab}}$ \\
\hline $18: 3 n-3$ & $0.7 \pm 0.3^{b}$ & $0.2 \pm 0.1^{\mathrm{a}}$ & $0.3 \pm 0.1^{\mathrm{a}}$ \\
\hline $18: 4 n-3$ & $1.3 \pm 1.6^{\mathrm{a}}$ & $0.4 \pm 0.2^{b}$ & $0.7 \pm 0.2^{\mathrm{ab}}$ \\
\hline $18: 5 n-3$ & $0.2 \pm 0.3$ & $0.2 \pm 0.1$ & $0.4 \pm 0.1$ \\
\hline $20: 4 n-6$ & $2.0 \pm 0.8^{\mathrm{a}}$ & $1.5 \pm 0.4^{\mathrm{ab}}$ & $1.1 \pm 0.2^{\mathrm{b}}$ \\
\hline $20: 4 n-3$ & $0.9 \pm 0.3^{b}$ & $0.5 \pm 0.2^{\mathrm{a}}$ & $0.4 \pm 0.1^{\mathrm{a}}$ \\
\hline $20: 5 n-3$ & $9.5 \pm 1.6^{\mathrm{a}}$ & $6.8 \pm 1.8^{b}$ & $9.2 \pm 2.4^{\mathrm{ab}}$ \\
\hline $21: 5 n-3$ & $0.5 \pm 0.1^{\mathrm{a}}$ & $0.2 \pm 0.1^{b}$ & $0.4 \pm 0.1^{\mathrm{a}}$ \\
\hline $22: 4 n-6$ & $0.5 \pm 0.4^{\mathrm{a}}$ & $0.5 \pm 0.2^{\mathrm{a}}$ & $0.2 \pm 0.1^{\mathrm{b}}$ \\
\hline $22: 5 n-3$ & $3.5 \pm 1.5^{b}$ & $1.8 \pm 0.7^{\mathrm{a}}$ & $1.0 \pm 0.3^{\mathrm{a}}$ \\
\hline $22: 6 n-3$ & $14.2 \pm 2.9^{\mathrm{a}}$ & $9.0 \pm 2.7^{b}$ & $4.7 \pm 1.1^{\mathrm{c}}$ \\
\hline$\sum$ PUFA & $35.9 \pm 4.1^{b}$ & $23.2 \pm 5.3^{\mathrm{a}}$ & $20.1 \pm 4.7^{\mathrm{a}}$ \\
\hline$\sum$ BAFA & $1.8 \pm 0.7^{\mathrm{a}}$ & $0.7 \pm 0.3^{b}$ & $1.4 \pm 0.3^{\mathrm{a}}$ \\
\hline$\sum n-3$ & $30.9 \pm 4.3^{b}$ & $19.4 \pm 4.8^{\mathrm{a}}$ & $17.3 \pm 4.2^{\mathrm{a}}$ \\
\hline$\sum n-6$ & $3.8 \pm 1.0^{\mathrm{b}}$ & $2.6 \pm 0.6^{\mathrm{a}}$ & $2.0 \pm 0.4^{\mathrm{a}}$ \\
\hline $20: 5 n-3 / 22: 6 n-3$ & 0.7 & 0.8 & 2 \\
\hline
\end{tabular}


Table 4 Correlations (40) between trace metals and tracers in Dakar. Only correlations with a coefficient $>0.5$ are shown. ${ }^{* *} \mathrm{p}<0.01 ; * * * \mathrm{p}<0.001$.

\begin{tabular}{|c|c|c|c|c|c|c|c|c|c|c|c|c|}
\hline Tracer & As & Cd & Co & $\mathrm{Cu}$ & $\mathbf{F e}$ & $\mathbf{L i}$ & Mn & $\mathbf{N i}$ & $\mathbf{P b}$ & Sn & $\mathbf{U}$ & $\mathbf{Z n}$ \\
\hline$\delta^{15} \mathbf{N}$ & & & & & $0.552 * *$ & $-0.678 * * *$ & & & & & & \\
\hline $14: 0$ & & & & & & & & & & & $0.507 * *$ & \\
\hline $15: 0$ & $0.520 * *$ & $0.544 * *$ & & & $\begin{array}{l}0.663 \\
* * *\end{array}$ & & $0.604 * * *$ & $0.611 * * *$ & $0.684 * * *$ & & & $0.745 * * *$ \\
\hline ant17:0 & & & & & & & $0.614 * * *$ & & $0.669 * * *$ & & & $0.776 * * *$ \\
\hline iso17:0 & & & & & & & & & $0.686 * * *$ & & & $0.633 * * *$ \\
\hline $17: 0$ & $0.512 * *$ & & & & & & & & & & & \\
\hline $18: 0$ & & & & & & & & & & & & $0.510 * *$ \\
\hline $17: 1 n-8$ & & & & & & $-0.522 * *$ & & & & & & \\
\hline 18 :1n-9 & & & & $-0.551 * *$ & & & $-0.569 * *$ & & & & & $-0.594 * *$ \\
\hline 18:1n-11 & & & & & & & & $0.533 * *$ & & & & \\
\hline $16: 3 n-6$ & & & & & & & & & $0.567 * *$ & & & \\
\hline $18: 2 n-4$ & & & & & & $-0.578 * *$ & & & $0.524 * *$ & $0.518 * *$ & & \\
\hline $20: 4 n-6$ & & & & & $0.580 * *$ & & $0.561 * *$ & & $0.638 * * *$ & & & $0.656 * * *$ \\
\hline $22: 4 n-6$ & $\begin{array}{c}0.609 \\
* * *\end{array}$ & & & & & & & & $0.559 * *$ & & & \\
\hline $22: 5 n-6$ & & & $0.529 * *$ & & $0.529 * *$ & & & & $0.783 * * *$ & & & \\
\hline $20: 5 n-3$ & & & & $\begin{array}{l}0.637 \\
* * *\end{array}$ & & & & & & & & \\
\hline $20: 4 n-3$ & & & & & & $0.564 * *$ & $0.596 * *$ & & & & & \\
\hline
\end{tabular}


Table 5 Correlations (28) between trace metals and tracers in Casamance. Only correlations with a coefficient $>0.5$ are shown. $* * \mathrm{p}<0.01 ; * * \mathrm{p}<0.001$.

\begin{tabular}{|c|c|c|c|c|c|c|c|c|c|c|}
\hline Tracer & Cd & Co & $\mathbf{C u}$ & $\mathrm{Fe}$ & $\mathbf{L i}$ & Mn & $\mathbf{N i}$ & $\mathbf{P b}$ & $\mathbf{U}$ & Zn \\
\hline$\delta^{13} \mathrm{C}$ & & & & & $-0.530 * * *$ & & & $0.574 * *$ & & \\
\hline $17: 0$ & $0.613 * * *$ & & & & & & & & & $0.531 * *$ \\
\hline $18: 0$ & & & & $0.594 * *$ & & & & & & \\
\hline $16: 1 n-7$ & & & & $-0.539 * *$ & & & & & & $-0.519 * *$ \\
\hline $16: 2 n-4$ & & & & & $0.584 * *$ & & & & & \\
\hline $16: 4 n-1$ & & $0.507 * *$ & & & & & & & & \\
\hline $18: 3 n-3$ & & & & & $0.593 * *$ & & & & & \\
\hline 20:1n-9 & & $0.554 * *$ & & & & & & & & \\
\hline $20: 4 n-3$ & & $0.659 * * *$ & & & $0.725 * * *$ & & & & & \\
\hline $20: 4 n-6$ & & & $0.693 * * *$ & & & & & $0.535 * *$ & & $0.557 * *$ \\
\hline $21: 5 n-3$ & & $0.594 * *$ & & & $0.667 * * *$ & & & & & \\
\hline $22: 4 n-6$ & & & & $0.554 * *$ & & & & & $0.513 * *$ & \\
\hline $22: 5 n-3$ & $0.621 * * *$ & $0.800 * * *$ & & & $0.640 * * *$ & & $0.502 * *$ & & $0.533 * *$ & \\
\hline $22: 6 n-3$ & & & $0.503 * *$ & & & $0.507 * *$ & & & & $0.598 * *$ \\
\hline
\end{tabular}


Table 6 Dietary origin of the metal elements inferred by tracers (SI and FA) in the two locations.

\begin{tabular}{|c|c|c|c|}
\hline Location & Metal & Origin & Tracer \\
\hline \multirow{13}{*}{ Dakar } & As & Benthos & $15: 0,17: 0,20: 4 n-6$ \\
\hline & Cd & Benthos & $15: 0$ \\
\hline & Co & Benthos & $22: 5 n-6$ \\
\hline & $\mathbf{F e}$ & Benthos & $15: 0,20: 4 n-6,22: 5 n-6$ \\
\hline & $\mathbf{N i}$ & Benthos & 15:0 \\
\hline & $\mathbf{P b}$ & Benthos & $15: 0$, ant17:0, iso17:0, 20:4n-6, 22:4n-6, $22: 5 n-6$ \\
\hline & Sn & Benthos & $\delta^{13} \mathrm{C}$ \\
\hline & $\mathbf{U}$ & Benthos & 14:0 \\
\hline & Zn & Benthos & $15: 0$, ant $17: 0$, iso $17: 0,20: 4 n-6$ \\
\hline & Mn & Benthos/Pelagos & $15: 0$, ant $17: 0,20: 4 n-6 / 20: 4 n-3$ \\
\hline & $\mathbf{C u}$ & Pelagos & $20: 5 n-3$ \\
\hline & $\mathbf{L i}$ & Pelagos & $20: 4 n-3$ \\
\hline & $\mathrm{Cr}$ & undefined & \\
\hline \multirow{13}{*}{ Casamance } & $\mathbf{P b}$ & Benthos & $\delta^{13} \mathrm{C}, 20: 4 n-6$ \\
\hline & Cd & Benthos/Pelagos & $17: 0 / 22: 5 n-3$ \\
\hline & $\mathbf{C u}$ & Benthos/Pelagos & $20: 4 n-6 / 22: 5 n-3$ \\
\hline & Zn & Benthos/Pelagos & $17: 0,20: 4 n-6 / 22: 6 n-3$ \\
\hline & Co & Pelagos & $20: 1 n-9,20: 4 n-3,21: 5 n-3,22: 5 n-3$ \\
\hline & $\mathbf{F e}$ & Pelagos & $22: 4 n-6$ \\
\hline & $\mathbf{L i}$ & Pelagos & $18: 3 n-3,20: 4 n-3,21: 5 n-3,22: 5 n-3$ \\
\hline & Mn & Pelagos & $22: 6 n-3$ \\
\hline & $\mathbf{N i}$ & Pelagos & $22: 5 n-3$ \\
\hline & $\mathbf{U}$ & Pelagos & $22: 4 n-6,22: 5 n-3$ \\
\hline & As & undefined & \\
\hline & $\mathrm{Cr}$ & undefined & \\
\hline & Sn & undefined & \\
\hline
\end{tabular}

